\title{
Synthetic plant defense elicitors
}

\author{
Yasemin Bektas ${ }^{1,2}$ and Thomas Eulgem ${ }^{1}$ * \\ ${ }^{1}$ Center for Plant Cell Biology, Institute for Integrative Genome Biology - Department of Botany and Plant Sciences, University of California, Riverside, CA, USA \\ ${ }^{2}$ Department of Biology, Faculty of Arts and Science, Gaziosmanpasa University, Tokat, Turkey
}

\section{Edited by:}

Erich Kombrink, Max Planck Institute for Plant Breeding Research, Germany

Reviewed by:

Raimund Tenhaken, University of Salzburg, Austria

Dierk Scheel, Leibniz Institute of Plant Biochemistry, Germany

${ }^{*}$ Correspondence:

Thomas Eulgem, Center for Plant Cell Biology, Institute for Integrative Genome Biology - Department of Botany and Plant Sciences, University of California, Riverside, CA 92521,

USA

e-mail: thomas.eulgem@ ucr.edu
To defend themselves against invading pathogens plants utilize a complex regulatory network that coordinates extensive transcriptional and metabolic reprogramming. Although many of the key players of this immunity-associated network are known, the details of its topology and dynamics are still poorly understood. As an alternative to forward and reverse genetic studies, chemical genetics-related approaches based on bioactive small molecules have gained substantial popularity in the analysis of biological pathways and networks. Use of such molecular probes can allow researchers to access biological space that was previously inaccessible to genetic analyses due to gene redundancy or lethality of mutations. Synthetic elicitors are small drug-like molecules that induce plant defense responses, but are distinct from known natural elicitors of plant immunity. While the discovery of some synthetic elicitors had already been reported in the 1970s, recent breakthroughs in combinatorial chemical synthesis now allow for inexpensive high-throughput screens for bioactive plant defense-inducing compounds. Along with powerful reverse genetics tools and resources available for model plants and crop systems, comprehensive collections of new synthetic elicitors will likely allow plant scientists to study the intricacies of plant defense signaling pathways and networks in an unparalleled fashion. As synthetic elicitors can protect crops from diseases, without the need to be directly toxic for pathogenic organisms, they may also serve as promising alternatives to conventional biocidal pesticides, which often are harmful for the environment, farmers and consumers. Here we are discussing various types of synthetic elicitors that have been used for studies on the plant immune system, their modes-of-action as well as their application in crop protection.

Keywords: plant activators, systemic acquired resistance, plant innate immunity, pesticide, crop protection, salicylic acid, chemical genetics, plant defense

\section{INTRODUCTION}

\section{THE PLANT IMMUNE SYSTEM}

Plants serve as a source of nutrients for a wide variety of heterotrophic microorganisms that can cause diseases in their hosts. Physical barriers, such as a waxy cuticular layer and rigid cell walls, as well as preformed antimicrobial chemicals can provide some protection against attacking phytopathogens (Nürnberger and Lipka, 2005). In addition, plants have evolved an inducible immune system that is based on the specific recognition of pathogen-derived molecules (Chisholm et al., 2006; Jones and Dangl, 2006). Two classes of plant immune receptors are critical for defense activation (Jones and Dangl, 2006; Dodds and Rathjen, 2010). Pattern recognition receptors (PRRs) directly interact with highly conserved microbe associated molecular patterns (MAMPs) activating pattern-triggered immunity (PTI; Gómez-Gómez and Boller, 2002; Zipfel et al., 2004; Segonzac and Zipfel, 2011). PTI can be attenuated or blocked by effector molecules that are secreted into plant cells by microbial pathogens that are well-adapted to their hosts (Abramovitch and Martin, 2004). The remaining weakened host immunity operating during such compatible plant/pathogen interactions [a state also referred to as effectortriggered susceptibility (ETS)] is called basal defense (Glazebrook et al., 2003; Chisholm et al., 2006; Jones and Dangl, 2006). While basal defense can limit the spread of virulent pathogens in their hosts, it is typically insufficient to prevent disease.

A second class of plant immune receptors, encoded by disease resistance $(R)$-genes, recognize the presence or activity of effectors and induce effector-triggered immunity (ETI), a manifestation of the well-described phenomenon of gene-for-gene resistance or race-specific resistance which leads to incompatible interactions (Flor, 1971; Nimchuk et al., 2003; Jones and Dangl, 2006; Elmore et al., 2011). ETI is a strong immune response that efficiently protects plants from avirulent pathogens and is often associated with the hypersensitive reaction (HR), a form of programmed death of plant cells at infection sites. Purified molecules or crude biochemical preparations from pathogens triggering PTI have also been referred to as general elicitors, while those triggering ETI, or race-specific resistance, have been termed race-specific elicitors (Wevelsiep et al., 1991).

Numerous studies have shown that ETI, basal defense and PTI utilize a common set of signaling components including multiple regulatory proteins, reactive oxygen intermediates (ROIs) as well as the phytohormones salicylic acid (SA), ethylene (ET) and jasmonic acid (JA; Nimchuk et al., 2003; Glazebrook, 2005; Spanu, 2012). Levels of ROI, SA, ET, or JA often increase in plant tissues after pathogen infections. While basal defense seems mainly to be 
a weakened form of PTI, ETI has been proposed to result from boosted basal defense- or PTI-associated responses (Tao et al., 2003; Jones and Dangl, 2006; Shen et al., 2007).

Inducible immune responses are tightly associated with extensive transcriptional- and metabolic-reprogramming controlled by a complex regulatory network (Glazebrook et al., 2003; Tsuda et al., 2009; Sato etal., 2010). While historically 10 classes of pathogenesis-related $(P R)$ genes had been recognized, which exhibit transcriptional up-regulation in defense-related biological situations (Kombrink and Somssich, 1997), more recent genomewide transcript profiling studies have revealed that 100-1000s of genes typically respond to defense induction by transiently altered transcript levels. Numerous signal transducers and transcription factors have been implicated in the plant defense network (Katagiri, 2004; Eulgem, 2005; Jones and Dangl, 2006). This network can be subdivided into various defined sectors that can interact with each other (Tsuda et al., 2009; Sato et al., 2010). For example, distinct defense signaling sectors dependent on early MAMP-activated MAP kinases (MAPKs) or the hormones SA or JA, have been described. Interestingly, some of these sectors were found to largely interact in an additive or synergistic fashion during PTI, while they are partially antagonistic to each other during ETI (Tsuda et al., 2009). The latter phenomenon seems to allow for compensatory effects if a defined sector is disabled due to interferences with pathogen effectors.

The complexity of this network is likely the result of two separate co-directional evolutionary pressures. Firstly, the asymmetrical arms race between plants and pathogens/pests manifested in continuous co-evolution of effectors and their host targets may have resulted in an ever-increasing diversity of plant defense regulators and regulatory circuits. Secondly, the need to fine-tune defense outputs appropriate for the respective attacker(s), which may exhibit biotrophic, hemibiotrophic, or nectrotrophic lifestyles, requires a complex regulatory system that allows for extensive crosstalk and compensatory interactions (Tsuda etal., 2009). An additional level of complexity likely arose from the need to link effector recognition mechanisms, which appear to be of recent evolutionary origin to more ancient regulatory processes mediating PTI (Chisholm et al., 2006; Holub, 2008).

While PTI, basal defense and ETI are transient local responses limited to pathogen infected tissues, plants can also activate long-lasting systemic immunity. Such systemic immunity can be initiated by local compatible or incompatible interactions resulting in systemic acquired resistance (SAR) or triggered by certain strains of non-pathogenic plant growth-promoting rhizobacteria (PGPR) leading to induced systemic resistance (ISR; Pieterse et al., 1998; van Wees et al., 2000). SAR mediates long-lasting broadspectrum resistance to a wide range of pathogens in uninfected tissues and organs (Ward et al., 1991; Fu and Dong, 2013). In addition to local pathogen infections, exogenous application of SA or SA analogs (see below) can induce SAR-like responses (White, 1979; Metraux et al., 1991; Ward et al., 1991). SAR and related systemic immune responses have been demonstrated in several plant systems, such as cucumber, watermelon, tobacco, and Arabidopsis thaliana (Arabidopsis; White, 1979; Kuc, 1982; Metraux et al., 1991; Ward et al., 1991). Typically SAR is associated with a local and systemic increase of SA levels that conditions enhanced expression of several classical PR genes (Rasmussen et al., 1991; Ward et al., 1991; Vernooij et al., 1994; Wildermuth et al., 2001; Durrant and Dong, 2004). Some of these PR genes, such as PR1, $P R 2$, and PR5 serve as robust markers for this systemic immune response (Kombrink and Somssich, 1997).

While local and systemic accumulation of SA is critical for SAR induction, this hormone seems not to serve as a mobile signal mediating immunity in uninfected distal tissues. Several other small molecules have been proposed to fulfill such a role, such as methyl-salicylic acid (MeSA), azelaic acid, glycerol-3-phosphate, the abietane diterpenoid dehydroabietinal, JA, and the amino acidderivative pipecolic acid (Park et al., 2007; Fu and Dong, 2013). A central regulator of SAR is the transcriptional co-factor NONEXPRESSOR OF PR GENES1 (NPR1; Dong, 2004). By interacting with TGA bZIP transcription factors, NPR1 seems to mediate up-regulation of the vast majority of SAR-associated genes (Fu and Dong, 2013). NPR1 activity has been proposed to be controlled by the SA-binding proteins NPR3 and NPR4, which can physically bind to NPR1 in a SA-concentration-dependent manner (Fu et al., 2012).

In contrast to SAR, induction of ISR is not associated with the accumulation of SA and PR transcripts (Sticher et al., 1997; van Wees et al., 2000). ISR has been shown to be triggered by the Pseudomonas fluorescens strain WCS417r (WCS417r) and other non-pathogenic rhizobacteria in several plant species including Arabidopsis (Wei et al., 1996; Sticher et al., 1997; Pieterse et al., 1998; Yan et al., 2002; Vallad and Goodman, 2004). In Arabidopsis, WCS417r-induced ISR acts against $P$. syringae pv. tomato, is dependent on JA and ET signaling, but does not require SA. Intriguingly, ISR is blocked in the Arabidopsis npr1 mutant. Thus, NPR1 also plays an important role in the ISR signaling pathway (Pieterse et al., 1998; Glazebrook, 2001).

Upon perception of several exogenous defense-related stimuli, plants can establish an enhanced capacity to activate immune responses. This sensitization process, which is called priming, can be triggered by treatment of plants with necrotizing pathogens, beneficial microorganisms, wounding or with various natural and synthetic compounds (Conrath et al., 2002, 2006; Conrath, 2006; Beckers and Conrath, 2007; Goellner and Conrath, 2008). Once a pathogen infects primed plants, defense responses are activated faster and more robustly (Conrath et al., 2006; Goellner and Conrath, 2008). Although this phenomenon has been known for years, its molecular basis is still only partly understood (Conrath, 2006, 2011; Conrath et al., 2006). Chromatin modifications, accumulation of dormant mitogen-activated protein kinases and alterations of primary metabolism have been shown to be associated with this process (Conrath et al., 2002, 2006; Beckers et al., 2009; Conrath, 2011; Jaskiewicz et al., 2011).

\section{A BRIEF HISTORY OF SYNTHETIC ELICITORS}

Synthetic elicitors are small molecules that can induce plant immune responses and are structurally distinct from natural plant defense inducers, such as general or race-specific elicitors or endogenous plant defense signaling molecules. Synthetic elicitors may trigger defense reactions by mimicking interactions of natural elicitors or defense signaling molecules with 
their respective cognate plant receptors or by interfering with other defense signaling components. Often the term "plant activators" is used for molecules that can protect plants from diseases by inducing immune responses. However, this term does not discriminate between synthetic and natural elicitors. One of the first synthetic elicitors was identified by Gianinazzi and Kassanis (1974), who found Polyacrylic acid derivatives of $3500 \mathrm{Da}$ or lower molecular weights to mediate resistance of tobacco (Nicotiana tabacum) against tobacco mosaic virus (TMV) or tobacco necrosis virus (TNV) and to activate PR1 gene expressions in tobacco (Gianinazzi and Kassanis, 1974; Kassanis and White, 1975). At the same time, 2,2-dichloro-3,3dimethylcyclopropane-carboxylic acid (WL28325) was described as a compound suitable for controlling rice blast in rice. WL28325 affects the phenol metabolism of rice plants by enhancing peroxidase activities (Langcake and Wickins, 1975a,b). Two years later, 3-allyloxy-1,2-benzisothiazole-1,1-dioxide, widely called Probenazole (PBZ), was described. It activates defense-related enzymes and triggers dramatic increases of tolerance against rice blast in rice. It has effectively been used in agriculture for over three decades against rice blast (Watanabe et al., 1977; Schreiber and Desveaux, 2008).

Exogenous application of SA and other benzoic acid derivatives, such as acetylsalicylic acid (Aspirin), was reported to induce resistance of tobacco against TMV and to cause the accumulation of PR-proteins (White, 1979). This discovery was a major breakthrough and paved the way for the identification of more potent related compounds by the Switzerland-based pharmaceutical corporation Ciba-Geigy (now Syngenta). Ciba-Geigy researchers reported 2,6-dichloro-isonicotinic acid (INA) and its ester derivative CGA 41397 as potent SAR-inducers in 1987. They also identified benzo(1,2,3)thiadiazole-7-carbothioic acid $S$-methyl ester (BTH), which has similar effects as INA, but was later found to be more suitable for applications in crop protection (Metraux et al., 1990; Ward et al., 1991; Friedrich et al., 1996; Görlach et al., 1996; Lawton et al., 1996; Uknes et al., 1996). As INA and BTH mimic the defense-associated effects of SA, but are less phytotoxic and more efficient than this natural plant defense hormone, they have been abundantly used as defense triggers in basic and applied studies on plant immunity. As outlined in detail below, these two compounds have been among the most frequently used synthetic elicitors in research for the past 15-20 years. However, recent improvements in combinatorial chemistry (Blackwell and Zhao, 2003; Stockwell, 2004; Dean, 2005; Raikhel and Pirrung, 2005) have enabled scientists outside the private sector to perform systematic screens for synthetic elicitors. Thus, a plethora of new compounds with defense-inducing properties distinct from INA and BTH or other established synthetic elicitors is currently emerging (Table 1). Such second-generation synthetic elicitors will equip researchers with an extensive repertoire of new chemical tools to dissect the plant defense network in an unprecedented fashion and to explore their use as active ingredients of novel types of pesticide alternatives and other agrochemicals.

\section{FUNCTIONAL ANALOGS OF SALICYLIC ACID}

The natural plant defense hormone SA (2-hydroxybenzoic acid) serves as an endogenous signal to activate certain immune responses and to establish disease resistance. Various defenserelated stimuli have been shown to trigger enhanced SA levels in local and systemic plant tissues. Exogenous application of SA can induce ROI production, $P R$ gene expression and immunity against various pathogens with biotrophic or hemibiotrophic lifestyles (Glazebrook, 2005; Vlot et al., 2009).

In plants, SA can be synthesized from the shikimate pathway-derived primary metabolite chorismate either via phenlypropanoid derivatives in the cytoplasm or via isochorismic acid in chloroplasts (Pieterse et al., 2012; An and Mou, 2014). Although both metabolic pathways are not fully understood, several of their enzymes have been identified. The production of SA and its levels are normally tightly regulated (Wildermuth, 2006). Critical for the production of the majority of defense-associated SA in Arabidopsis is isochorismate synthase 1 (ICS1), which is transcriptionally induced by defense-related stimuli (Wildermuth et al., 2001). Two distinct forms of SA glucosyltransferase (SAGT) enzymes convert most of the produced SA to either salicyloyl glucose ester (SGE) or SA-O- $\beta$-glucoside (SAG), which is stored in the vacuole. Additional SA derivatives are known in plants, such as MeSA. SAG, SGE, and MeSA are likely biologically inactive (Vlot et al., 2009; Fu and Dong, 2013).

Salicylic acid plays a pivotal role in defense signaling and several proteins have been proposed to bind to SA and to potentially serve as SA receptors. The first putative SA-binding protein reported in the literature was SABP1 from tobacco, a potential catalase (Chen et al., 1993). It was proposed that SA inhibits its ability to convert $\mathrm{H}_{2} \mathrm{O}_{2}$ to $\mathrm{O}_{2}$ and $\mathrm{H}_{2} \mathrm{O}$ (Conrath et al., 1995; Du and Klessig, 1997; Vlot et al., 2009). However, this claim is controversial, as much higher SA-concentrations seem to be needed for catalase inhibition than observed in defense-activated plants (Chamnongpol et al., 1996; Tenhaken and Rubel, 1997). Similarly, it was shown that SA can also bind to ascorbate peroxidase (APX) and inhibit its activity upon application of high concentrations of exogenous SA (Durner and Klessig, 1995; Vlot et al., 2009). An additional tobacco SA-binding protein, SABP2, functions as a MeSA esterase. SABP2 shows a high binding affinity for SA, which inhibits its esterase activity (Kumar and Klessig, 2003; Forouhar et al., 2005). SABP2 seems to play an important role in the activation of SAR in tobacco by catalyzing the release of SA from the transport metabolite MeSA in systemic tissues (Park et al., 2007). Another SA-binding protein, SABP3, a tobacco chloroplastic carbonic anhydrase, is involved in HR and has antioxidant function (Slaymaker et al., 2002; Vlot et al., 2009). However, it remains to be determined whether this function can affect plant defense.

In Arabidopsis, NPR1 plays a critical role in the interpretation of the SA signal. NPR1 is responsible for activating a large set of defense genes in response to SA-related signals (Dong, 2004; Fu and Dong, 2013). Moreover, the NPR1 paralogues NPR3 and NPR4 function as SA receptors, and their interactions with NPR1 are directly regulated by binding to SA (Fu et al., 2012). In addition, NPR1 itself has also been shown to be capable of binding SA independently of NPR3 and NPR4 and to respond to interactions with this ligand by conformational changes (Wu et al., 2012).

With several proteins capable of binding to SA, defense mechanisms controlled by this phytohormone feature a set of "drug-able" targets potentially interfering with SA-related synthetic molecules. 


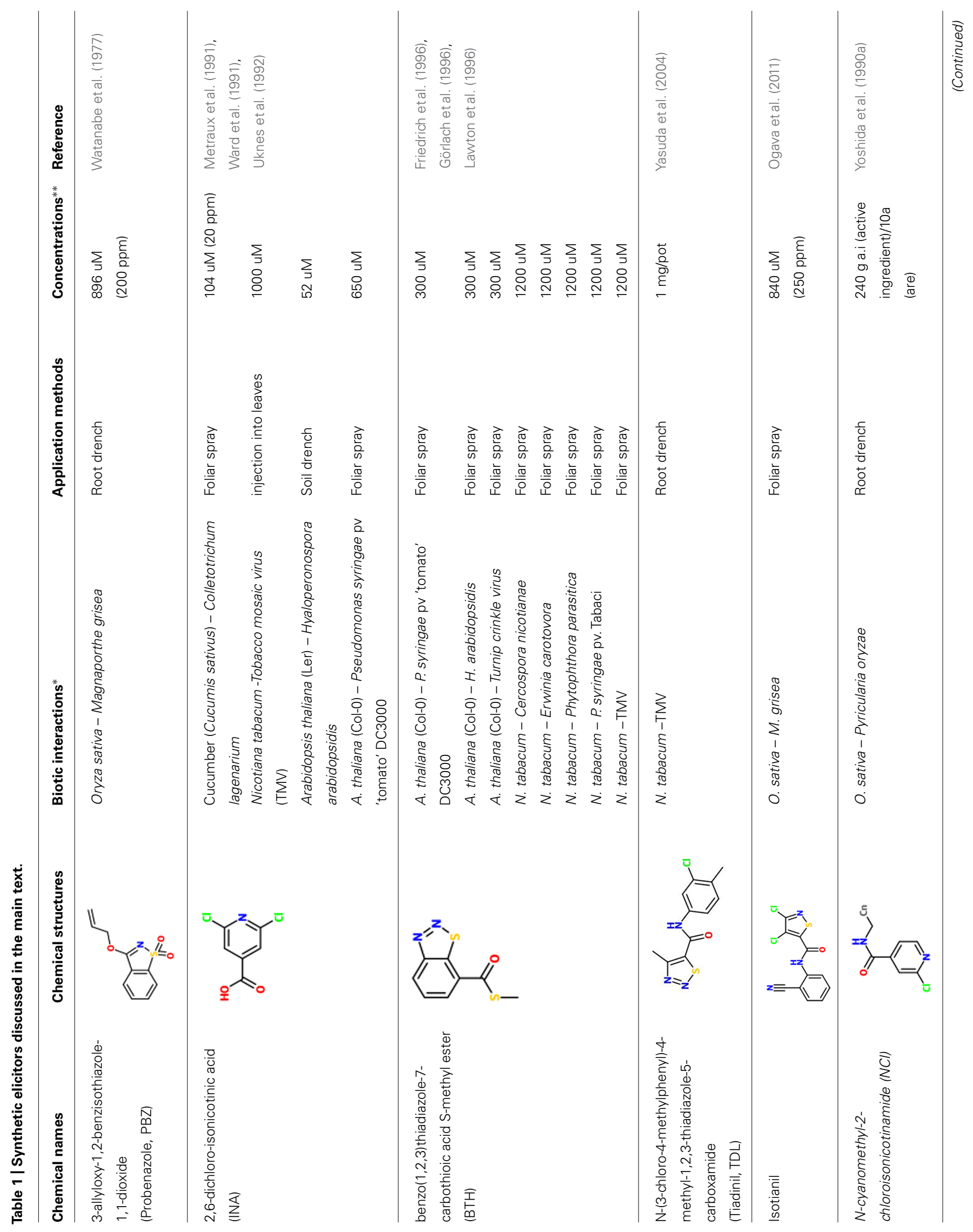




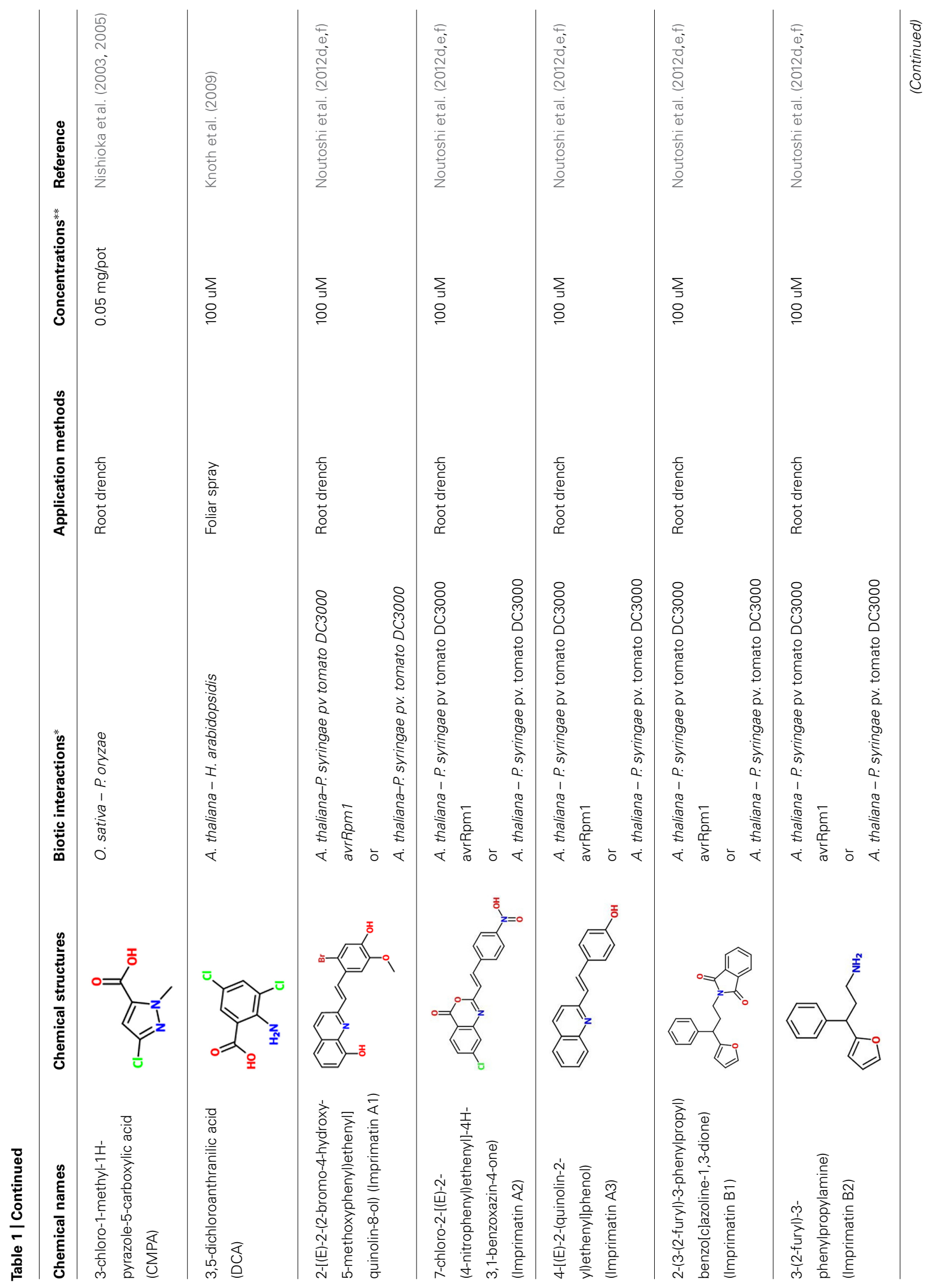




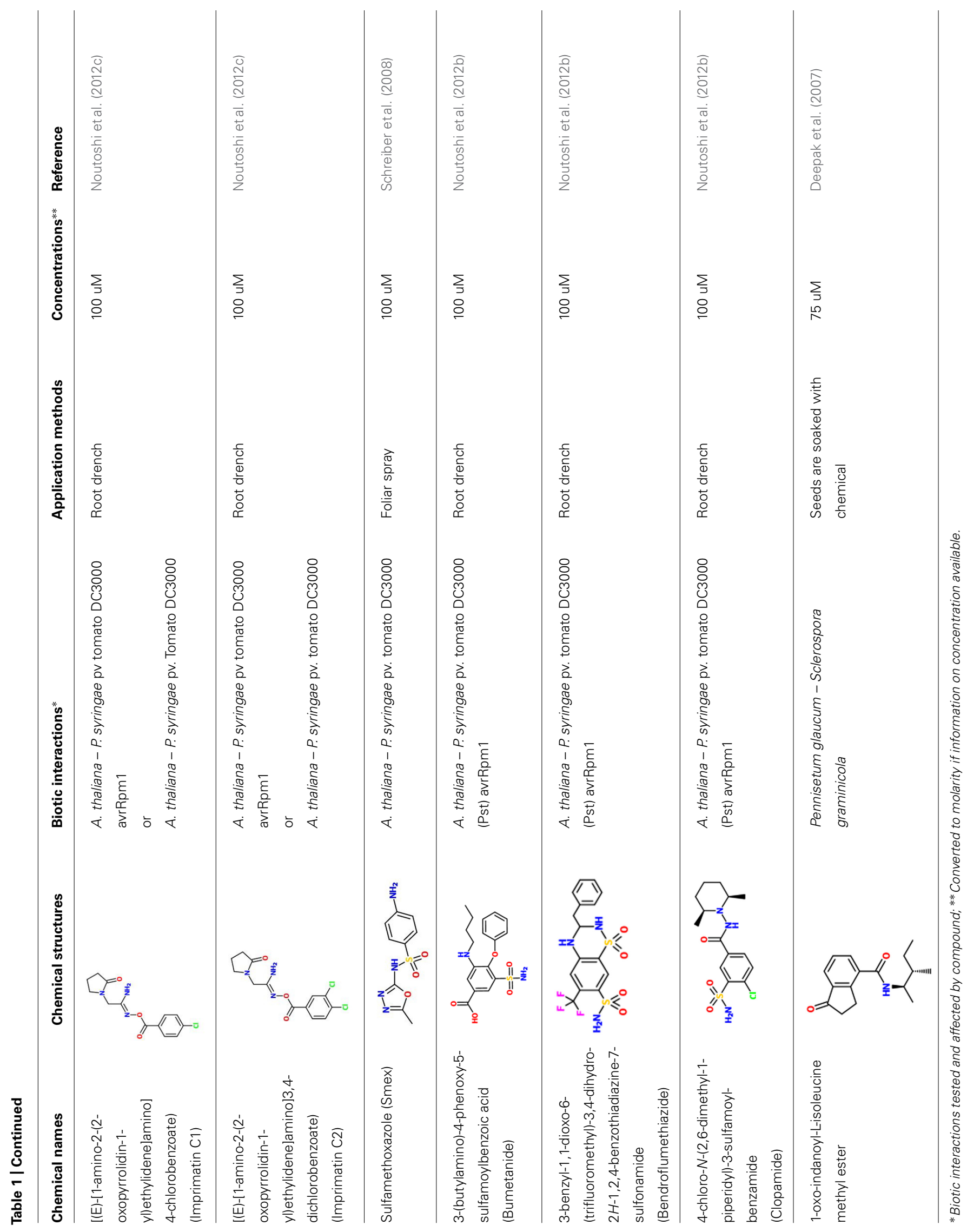


Consequently, some synthetic elicitors have been found to mimic a subset of known SA functions; likely by directly interfering with known or unknown receptors of this defense hormone. Besides such SA agonists, which molecularly mimic SA, other synthetic elicitors may trigger transcriptional and physiological responses related to those induced by SA without directly interfering with SA targets. For this review we consider both types of SA mimics as functional SA analogs. Synthetic elicitors of this type are described in the section, below.

\section{PROBENAZOLE (PBZ)}

Several biologically active 1,2-benzisothiazole derivatives have been found to exhibit a broad spectrum of pharmacological activities and to serve as antibacterials, fungicides and antiinflammatory agents (De, 1981; Trapani et al., 1985; Zani et al., 1996; Vicini etal., 2002). Some of them also show auxinlike activity and have been used as herbicides (Giannella et al., 1971; Branca etal., 1975). Inspired by the potency of some of these compounds, researchers of Meiji Seika Kaisha Ltd. in Japan performed systematic tests with representatives of this class of molecules (Watanabe et al., 1977). They found 3-allyloxy1,2-benzisothiazole-1,1-dioxide (now widely known as PBZ), to efficiently control rice blast (Magnaporthe oryzae; anamorph: Pyricularia oryzae) infections in rice (Oryza sativa; Watanabe et al., 1977; Schreiber and Desveaux, 2008). This compound showed remarkable effects in suppressing rice blast at a dose of $896 \mathrm{uM}$ (200 ppm) when applied by drenching roots (Watanabe et al., 1977) and has been commercially used under the name Oryzemate ${ }^{\circledR}$ for more than 30 years in the field protecting rice from rice blast fungus and bacterial leaf blight as well as corn from southern corn leaf blight (Iwata, 2001; Oostendorp et al., 2001). PBZ does not influence the growth of various tested crops, such as tomato, cucumber, Chinese cabbage, kidney bean, or rice, when sprayed at a concentration of $2240 \mathrm{uM}$ (500 ppm), but at $4480 \mathrm{uM}$ (1000 ppm) some abnormalities in plant development can be observed (Watanabe et al., 1977).

Probenazole affects various stages of the blast fungus infection cycle and inhibits hyphal penetration into the host tissue, lesion expansion and sporulation (Watanabe et al., 1977). From PBZ-treated rice plants anticonidial germination substances were isolated and characterized as toxic against fungi. These antifungal plant metabolites included a mixture of fatty acids, such as octadecatrienoic acid, palmitic acid, linoleic acid, and linolenic acid (Sekizawa et al., 1981; Shimura et al., 1983). Moreover, activities of defense-related enzymes, such as peroxidase, polyphenoloxidase, PAL, tyrosine ammonia-lyase and catechol-O-methyltransferase, increased dramatically in rice upon treatment with PBZ, as they do in response to infection with rice blast fungus (Midoh and Iwata, 1996; Iwata, 2001).

A PBZ-induced cDNA termed PBZ-responsive gene (PBZ1) has been cloned from rice. PBZ1 transcript accumulation was found to serve as a robust marker for responses to this synthetic elicitor. PBZ-induced PBZ1 mRNA accumulates in a dose-dependent manner. $P B Z 1$ expression is also induced by rice blast fungus, but not wounding. $P B Z 1$ belongs to the $P R$ 10 family of classical $P R$ genes. One of the metabolites of PBZ, 1,2-benzisothiazole-3(2H)-one-1,1-dioxide (BIT) was found to be as potent in inhibiting rice blast as PBZ, but does not induce the accumulation of the PBZ1 transcripts (Midoh and Iwata, 1996; Nakashita et al., 2001, 2002b; Yoshioka et al., 2001). Thus, induced $P B Z 1$ expression seems not to be needed for rice blast resistance.

Microarray and RT-PCR analysis revealed up-regulation of UDP-glucose:SA glucosyltransferase (OsSGT1) transcripts in response to PBZ treatment in rice (Umemura et al., 2009). RNAimediated OsSGT1 knockdown in transgenic rice plants resulted in reduced PBZ-mediated resistance against blast. Although mechanistic details of its role in defense induction are unclear, OsSGT1 appears to be critical for PBZ-mediated defense induction (Umemura et al., 2009).

In Arabidopsis, both PBZ and its metabolite BIT stimulate expression of $P R$ genes and induce SA accumulation and SAR. PBZ and BIT do not activate plant immunity in npr1 mutants or nah $G$ plants. Thus, SA and NPR1 seem to be required for PBZand BIT-mediated defense responses and both compounds mimic effects of SA (Yoshioka et al., 2001; Nakashita et al., 2002b). However, in contrast to INA, BTH, and DCA, which are likely authentic SA agonists (see below), PBZ and BIT appear to interfere with defense signaling steps upstream from SA accumulation and not to interact with downstream targets of SA.

\section{2,6-DICHLORO-ISONICOTINIC ACID (INA)}

Kunz etal. (1988) of Ciba-Geigy reported screening of a large number of compounds for activation of resistance in cucumber (Cucumis sativus) against the fungal pathogen Colletotrichum lagenarium and identified 2,6-dichloro-isonicotinic acid (INA) and its ester derivative CGA41397 (Kunz et al., 1988; Metraux et al., 1991). High levels of protection of cucumber against C. lagenarium, were achieved by foliar-spray application of $104 \mathrm{uM} \mathrm{(20} \mathrm{ppm)}$ INA or CGA41397 as well as root drench application of 10-fold lower concentrations of each compound. In these chemicallytreated plants, responses were similar to those observed in systemic tissues of plants whose lower leaves were inoculated with TNV or C. lagenarium that induce SAR in upper leaves. Under field conditions, INA provided pathogen resistance in pear, pepper and rice (Kuc, 1982; Metraux et al., 1991). INA was also shown to induce SAR in tobacco and Arabidopsis (Ward et al., 1991; Uknes et al., 1992) and provide significant protection of tobacco against TMV, Cercospora nicotianae, Peronospora tabacina, Phytophthora parasitica var nicotianae, and P. syringae pv. tabaci (Ward et al., 1991).

In Arabidopsis INA can trigger long-lasting $P R$ gene expression and disease resistance. In this species it can reduce susceptibility to virulent strains of the oomycete Hyaloperonospora arabidopsidis (Hpa) or P. syringae pv. tomato DC3000 without directly affecting viability of these pathogens (Uknes et al., 1992; Knoth et al., 2009). As injection of 1 mM INA into tobacco leaves induces transcript accumulation of the same characteristic set of $P R$ genes as SA application, it is considered a functional SA analog. Although INA partially mimics defense-associated effects of SA, it does not trigger any changes of SA levels and, unlike SA or PBZ, induces SAR in nah $G$ transgenic tobacco and Arabidopsis plants (Delaney et al., 1994; Vernooij etal., 1995). Thus, INA must be interfering with targets that operate downstream from SA accumulation 
and are likely involved in the interpretation of SA levels. Consistent with this assumption, INA has been reported to mimic several proposed biochemical and physiological effects of SA, such as inhibition of catalase and APX activity or the induction of cellular $\mathrm{H}_{2} \mathrm{O}_{2}$ accumulation (Chen and Klessig, 1991; Chen et al., 1993, 1995; Conrath et al., 1995; Durner and Klessig, 1995). The modulation of ROI levels seems to be a critical aspect of INA activity, since antioxidants can block the INA-dependent induction of PR gene expression (Chen et al., 1995; Durner and Klessig, 1995).

Through mutant screens to identify genes required for SAR in Arabidopsis, the npr1/nim1 (non-expresser of $P R$ genes 1, no immunity 1) mutants that are insensitive to SA and INA were discovered (Cao et al., 1994; Delaney et al., 1995). Both biologicallyand INA-induced SAR as well as basal defense were found to be compromised in either one of these mutants. The npr1 and nim 1 mutants are in different Arabidopsis accessions, but were found to be allelic and to have defects in the same gene (Cao et al., 1994, 1997; Ryals et al., 1997). A large body of literature has reported on molecular roles of NPR1 as a transcriptional cofactor, since its identification as a major regulator of SAR. These studies have been summarized in several excellent reviews (Dong, 2004; Durrant and Dong, 2004; Fu and Dong, 2013). Most importantly, NPR1, together with NPR3 or NPR4, have been found to serve as SA receptors (Fu et al., 2012; Fu and Dong, 2013). NPR3 can bind to NPR1 in a SA dose-dependent manner, while NPR4-NPR1 interactions are constitutive and inhibited by SA. In yeast two-hybrid assays, in addition to SA, INA can promote NPR1-NPR3 interactions. INA can also reduce the binding affinity of SA to NPR3 and NPR4 by competing with this defense hormone (Fu et al., 2012). Thus, INA appears to be a true SA agonist.

In addition to npr 1 mutants, triple or quadruple mutants of closely related TGA-bZIP transcription factors, which are known to physically interact with NPR1, are also blocked in INA-induced PR gene expression and pathogen resistance (Zhang et al., 2003; Wang et al., 2006). Thus, INA seems to mediate its defense-related effects upon interactions with NPR1-related proteins, which control several TGA transcription factors. Interactions with other SA-binding proteins, such as SABP1 and SABP2 may also to contribute to the activity of this SA analog. So far, INA has been applied to many plant species and was found to induce resistance against a wide variety of pathogens (Hijwegen and Verhaar, 1993; Conrath et al., 1995; Van Kan et al., 1995; Han et al., 2000; Lee et al., 2009). However, because INA and its derivatives have phytotoxic side effects in crops, none of these compounds has been commercialized as agrochemicals (Oostendorp et al., 2001). Still, INA is being continually used as an efficient chemical tool to study SAR.

\section{BENZOTHIADIAZOLE (BTH)}

Another SAR-inducer screening by Ciba-Geigy with a large number of benzo[1,2,3] thiadiazole-7-carboxylic acid derivatives resulted in the identification of benzo(1,2,3)-thiadiazole7-carbothioic acid S-methyl-ester [benzothiadiazole (BTH); acibenzolar-S- methyl (ASM), CGA245704] as a potent inducer of plant immune responses (Schurter et al., 1993; Kunz et al., 1997; Oostendorp et al., 2001). BTH was subsequently shown to trigger in various plant species resistance against a wide variety of pathogens, such as TMV, Cercospora nicotianae, Erwinia carotovora, Phytophthora parasitica and P. syringae pv. tabaci (Friedrich et al., 1996; Görlach et al., 1996; Lawton et al., 1996; Kunz et al., 1997). As BTH did not show any direct effect on a number of plant pathogens in vitro, BTH is not antimicrobial (Friedrich et al., 1996). In Arabidopsis, BTH triggers NPR1-dependent SAR (Lawton et al., 1996).

At the molecular level, BTH induces the same characteristic set of SAR-related responses that are induced by pathogens or SA, including up-regulation of $P R$ genes. Thus, like INA, BTH appears to be a functional analog of SA (Friedrich et al., 1996; Wendehenne et al., 1998). INA and BTH share several characteristic functional features. Both compounds do not induce accumulation of SA in plants (Vernooij et al., 1995; Friedrich et al., 1996) and share the ability to induce SAR and $P R$ gene expression in transgenic nah $G$ lines (Vernooij et al., 1995; Lawton et al., 1996). Thus, both INA and BTH seem to activate SA-response mechanisms by interfering as SA agonists with targets operating downstream from SA accumulation. Like SA and INA, BTH was also proposed to inhibit both APX and catalase functions (Du and Klessig, 1997; Wendehenne et al., 1998). However, BTH is a much more effective inhibitor of catalase than SA and the catalase inhibition mechanisms of BTH and $\mathrm{SA}$ are different. While SA seems to inhibit catalase function in an $\mathrm{H}_{2} \mathrm{O}_{2}$ - and time-dependent manner, BTH inhibits this activity independently from time and $\mathrm{H}_{2} \mathrm{O}_{2}$. INA was not included in these experiments. For APX inhibition, however, BTH and SA exhibit similar dose-response curves (Wendehenne et al., 1998).

Recent data suggested that BTH is converted into acibenzolar by SABP2 and this product is critical for SAR induction. When $\mathrm{BTH}$ was sprayed on SABP2-silenced tobacco plants, it failed to induce PR1 protein expression and SAR. On the contrary, when the same transgenic plants were treated with acibenzolar, SAR was fully induced (Tripathi et al., 2010).

In rice, it was shown that the OsWRKY45 transcription factor plays a pivotal role in $\mathrm{BTH}$-induced defense responses against rice blast disease. This BTH-triggered defense mechanism seems independent of NH1, a rice ortholog of A. thaliana NPR1 (Shimono et al., 2007). WRKY45 knockdown lines exhibited strongly reduced levels of BTH-induced resistance to the fungal pathogen $M$. oryzae and the bacterial pathogen Xanthomonas oryzae pv. oryzae (Xoo; Shimono et al., 2007). Interestingly, OsWRKY45 is an ortholog of AtWRKY70, which also can act in an NPR1-independent manner in SA signaling in Arabidopsis (Li et al., 2004; Knoth et al., 2007, 2009). In addition to BTH, PBZ and Tiadinil (TDL; see below) partly induced blast resistance in rice through a WRKY45dependent pathway (Shimono et al., 2012). Recently, WRKY45regulated $\mathrm{BTH}$-responsive genes were identified by microarrays (Nakayama et al., 2013).

BTH can also prime plant defense reactions. Low doses of BTH that are insufficient to trigger detectable levels of defense responses, can prime parsley cells and increase their sensitivity for MAMP-triggered coumarin phytoalexin secretion. This effect is associated with potentiated activation of genes encoding phenylalanine ammonia-lyase (PAL), which is critical for coumarin biosynthesis. In addition to BTH, also SA and INA can prime parsley cells for the activation of coumarin secretion by low MAMP doses (Kauss et al., 1992; Katz et al., 1998; 
Thulke and Conrath, 1998; Conrath et al., 2002). BTH can also prime Arabidopsis plants for enhanced pathogen-responsiveness of PAL gene expression. BTH-mediated defense priming in Arabidopsis is dependent on NPR1 (Kohler et al., 2002; Goellner and Conrath, 2008). An interesting mechanism involving two known defense-associated MAPKs, MPK3, and MPK6, seems to contribute to this priming phenomenon in Arabidopsis. BTH induces the accumulation of $\mathrm{mRNA}$ and inactive protein forms of both MAPKs. Subsequent stress treatment results in phosphorylation and activation of MPK3 and MPK6 (Beckers et al., 2009). In addition, epigenetic chromatin marks appear to be involved in defense-priming processes. The AtWRKY29, AtWRKY6, and AtWRKY53 genes showed a typical priming response and were strongly transcribed after stress application following pre-treatment with BTH. BTH pre-treatment also triggered in these experiments various histone modifications that are typically found at actively transcribed genes, such as $\mathrm{H} 3 \mathrm{~K} 4 \mathrm{me} 3$, $\mathrm{H} 3 \mathrm{~K} 4 \mathrm{me} 2, \mathrm{H} 3 \mathrm{ac}$, or H4ac at AtWRKY29 and H3K4me3 or $\mathrm{H} 3 \mathrm{~K} 4 \mathrm{me} 2$ at AtWRKY6 and AtWRKY53. BTH-induced trimethylation of $\mathrm{H} 3 \mathrm{~K} 4$ is reduced in the priming-deficient npr1 mutant. On the contrary, the constitutively primed cpr1 and snil mutants exhibit high levels of H3K4me3 in the absence of BTH treatment. Thus, elevated $\mathrm{H} 3 \mathrm{~K} 4 \mathrm{me} 3$ levels are closely associated with BTH-induced defense gene priming (Jaskiewicz et al., 2011).

In contrast to INA, BTH was found to be suitable for agricultural crop protection. It became a commercial product under the trade name of $\mathrm{BION}^{\circledR}$ (in Europe) in 1989 and Actigard ${ }^{\circledR}$ (in the US) in 1990 (Schurter et al., 1993; Kunz et al., 1997; Oostendorp et al., 2001). BTH activates very wide spectrum of resistances of various plant species against fungal, bacterial, or viral pathogens and several insects and nematodes.

\section{N-(3-CHLORO-4-METHYLPHENYL)-4-METHYL-1,2,3-THIADIAZOLE-5- CARBOXAMIDE (TIADINIL, TDL)}

Thiadiazoles are known to have many pharmacological activities (Camoutsis et al., 2010; Chaudhary et al., 2010; Kharb et al., 2011; Singh et al., 2011). Tests of various 1,2,3-thiadiazole derivatives for their ability to control rice blast disease by Nihon Nohyaku Co., Ltd. (Japan) resulted in the discovery of $N$-(3-chloro4-methylphenyl)-4-methyl-1,2,3-thiadiazole-5-carboxamide (Tiadinil, TDL), which provided protection against this disease without exhibiting any antimicrobial activity (Tsubata et al., 2006). Since 2003, this compound has been commercially available under the trade name V-GET ${ }^{\circledR}$ in Japan. Its metabolite 4-methyl-1,2,3thiadiazole-5-carboxylic acid (SV-03), exhibited similar levels of anti-rice blast activity as TDL (Tsubata et al., 2006; Toquin et al., 2012). In addition to rice blast, TDL is also used to control the pathogenic fungi Colletotrichum theaesinensis and Pestalotiopsis longiseta on tea leaves (Yoshida et al., 2010).

In tobacco, TDL and SV-03 induce SAR and increased local resistance to TMV, the virulent bacterial pathogen $P$. syringae pv. tabaci and powdery mildew (Oidium lycopersici) without affecting these pathogens directly. Both compounds also induce PR1, PR2 and PR5 gene expression in Arabidopsis and enhance basal resistance of this species to $P$. syringae pv. tomato DC3000 (Yasuda et al., 2004, 2006; Yasuda, 2007). TDL or SV-03 treatment does not induce accumulation of SA in tobacco. Moreover, TDL or SV-03-treated nahG transgenic tobacco plants exhibit enhanced resistance to TMV and $P$. syringae pv. tabaci and induced $P R$ gene expression. However, TDL- or SV-03-triggered defense responses are blocked in Arabidopsis npr1 mutants. Taken together, these results suggest that, similar to BTH and INA, TDL and SV-03 trigger disease resistance by interfering with signaling steps downstream of SA (Yasuda et al., 2006; Yasuda, 2007).

The thiadiazole derivative, 1,3,4-oxadiazole, has also been shown to exhibit antifungal and antibacterial activities (Kharb et al., 2011; Singh et al., 2011). By combining different heterocyclic thiadiazole-related moieties, including oxadiazoles, new compounds were designed and evaluated regarding their performance in crop disease protection. Although only three out of the 23 tested compounds elicited SAR more efficiently than TDL, combining thiazole- and oxadiazole moieties may be a promising approach in designing new crop protectants (Fan et al., 2009).

\section{ISOTIANIL}

As a result of a comprehensive search for isothiazole-based compounds, Isotianil was discovered by Bayer AG (now Bayer CropScience AG) in Germany in 1997 and developed jointly with the Japanese company Sumitomo Chemical Co., Ltd. as a crop protectant against rice blast and bacterial leaf blight in rice. It also activates defense responses against a wide range of additional pathogens in various plants. Moreover, Isotianil does not show any direct antimicrobial activity against bacteria and fungi (Ogava et al., 2011; Toquin et al., 2012). In 2010, it was registered under the name Stout ${ }^{\circledR}$ in Japan and China, where it substantially increased rice production (Ogava et al., 2011; Brozek et al., 2012; Yoshida et al., 2013). Its efficiency against rice blast seems unusually high, as lower dosages of Isotianil are needed than of any other existing plant defense activator, such as PBZ and TDL (Ogava et al., 2011).

At the molecular level, Isotianil treatment triggers accumulation of defense-related enzymes such as lipoxygenase or $\mathrm{PAL}$ in rice. Affymetrix whole genome microarray analysis revealed that Isotianil treatment induces some defense-related genes, including OsWRKY45, that are involved in SA signaling (Ogava et al., 2011; Toquin et al., 2012). Further microarray analyses showed that Isotianil likely primes rice for more intense defense activation in response to pathogen infections. At this point no published information on its mode-of-action is available.

\section{N-CYANOMETHYL-2-CHLOROISONICOTINAMIDE (NCI)}

A screen of 2-chloroisonicotinamide derivatives for effective rice blast control agents were performed by Nihon Nohyaku Co., Ltd. (Japan), resulted in the identification of $\mathrm{N}$-cyanomethyl-2chloroisonicotinamide (NCI) as a potent defense inducer (Yoshida et al., 1989, 1990a,b). NCI showed one of the highest anti-blast activities compared to other $N$-alkyl-2-chloroisonicotinamides and its efficacy was equal to that of PBZ. It does not show antifungal activity against rice blast in vitro at concentrations as high as $1100 \mathrm{uM}(500 \mathrm{ppm})$. Its activity is long-lasting, as it was found to be still effective against rice blast 30 days after a single application. 
NCI treatment inhibits mycelial development of $P$. oryzae at inner epidermal cells and increases the number of small brownish lesions that are correlated with active immunity of rice. These results suggest that NCI efficiently induces plant defense mechanisms (Yoshida et al., 1990a).

In tobacco, NCI can induce SAR and mediate local resistance to TMV, Oidium lycopersici and P. syringae pv. tabaci. It also induces expression of $P R 1, P R 2$ and $P R 5$ and is active in transgenic $n a h G$ tobacco plants. Thus, it does not require SA for activation of defense (Nakashita et al., 2002a). In Arabidopsis, NCI reduces growth of virulent $P$. syringae and induces resistance independently from SA accumulation, ET and JA, but requires NPR1. Thus, like INA and BTH, NCI seems to interfere with defense signaling steps operating between SA and NPR1 (Yasuda et al., 2003a; Yasuda, 2007).

\section{3-CHLORO-1-METHYL-1H-PYRAZOLE-5-CARBOXYLIC ACID (CMPA)}

A screen by Nishioka etal. (2003) targeting new chemicals to control blast disease in rice resulted in the discovery of pyrazolecarboxylic acid derivatives as potent inducers of systemic immunity. The most efficient anti-blast compound identified in this screen was 3-chloro-1-methyl-1H-pyrazole-5-carboxylic acid (CMPA). CMPA does not directly affect pathogen viability up to a concentration of $623 \mathrm{uM}$ (100 ppm), while it can significantly induce rice blast resistance at 10 -fold lower concentrations. Thus, its antiblast activity is not dependent on antimicrobial activity and this compound seems to activate systemic plant defense mechanisms (Nishioka et al., 2003). Although, CMPA, BTH, and PBZ trigger rice blast resistance with similar efficacies, CMPA induces PBZ1 transcript accumulation in rice at levels lower than PBZ or BTH (Nishioka et al., 2005).

In tobacco, CMPA enhances resistance to $P$. syringae pv. tabaci and Oidium sp.. CMPA also induces expression of $P R 1, P R 2$, and $P R 5$ in wild-type as well as nah $G$ transgenic tobacco. Therefore, CMPA seems not to require SA to induce SAR-like disease resistance and may interfere with defense signaling downstream from SA. Consistent with this assumption, CMPA was found to act through NPR1 in Arabidopsis (Yasuda et al., 2003b; Yasuda, 2007).

\section{3,5-DICHLOROANTHRANILIC ACID (DCA)}

The compound 3,5-dichloroanthranilic acid (DCA) is one of 114 synthetic elicitor candidates that were identified by a comprehensive screening of 60,000 diverse compounds for inducers of the pathogen-responsive CaBP22::GUS reporter gene in Arabidopsis (Knoth etal., 2009; Knoth and Eulgem, 2014). DCA efficiently triggers resistance of Arabidopsis against virulent strains of the oomycete Hpa and P. syringae DC3000. It up-regulates transcript levels of various known SA-responsive defense-related genes, such as PR1, WRKY70, and CaBP22. Like INA and $\mathrm{BTH}$, its activity does not require accumulation of SA. However, unlike these well-characterized SA analogs, DCA-mediated immunity is not fully blocked in nprl Arabidopsis mutants. DCA-triggered immune responses are to a large extent independent from NPR1, but partially blocked in wrky70 mutants. Thus DCA partially targets a WRKY70-dependent branch of the defense signaling network that does not require NPR1 (Knoth et al., 2009).
Microarray analyses revealed that DCA, INA, and BTH trigger partially overlapping transcriptional responses in Arabidopsis (Wang et al., 2006; Knoth et al., 2009; Bhattarai et al., 2010). For example, transcripts of a set of 202 genes were found to be commonly up-regulated by each one of these three synthetic elicitors. However, DCA, INA, and BTH also induce unique transcriptional changes. Taken together, these and other observations suggest that each of these SA analogs interferes with targets in the SA response pathway in a unique manner.

\section{ADDITIONAL FUNCTIONAL ANALOGS OF SA}

Besides the functional analogs of SA that are discussed above, additional derivatives of this defense hormone were tested (Conrath et al., 1995; Knoth et al., 2009). This includes 3,5-dichlorosalicylic acid, 4-chlorosalicylic acid, and 5-chlorosalicylic acid, which mimic SA, induce PR1 gene expression and enhance disease resistance to TMV infection in tobacco (Conrath et al., 1995). Furthermore, 3-chlorobenzoic acid and 3,5-dichlorobenzoic acid induce basal defense against Hpa as well as CaBP22::GUS expression in Arabidopsis (Knoth et al., 2009). In contrast, the SA-related compounds benzoic acid, 2-aminobenzoic acid, 3-hydroxybenzoic acid, 4-hydroxybenzoic acid, 2,3-dihydroxybenzoic acid, 2,4dihydroxybenzoic acid, 2,5-dihydroxybenzoic acid, and 4amino-SA did not show any defense-inducing activity (Chen and Klessig, 1991; Conrath etal., 1995; Durner and Klessig, 1995).

Furthermore, several agonists of the peroxisome proliferatoractivated receptor were found to mimic effects of SA in local HR responses, but not $P R$ gene expression or SAR, in soybean. The latter finding suggested that the roles of SA in local and systemic defense induction are distinct (Tenhaken et al., 2001).

\section{IMPRIMATINS}

A screen of 10,000 small molecules to identify plant immune priming compounds by Noutoshi et al. (2012d) and coworkers resulted in the identification of three distinct classes of compounds that can prime Arabidopsis cells to exhibit enhanced immunity against virulent and avirulent $P$. syringae. These immune-priming compounds were termed Imprimatins. Based on structural similarities they were classified as Imprimatin A, - B or -C, representatives, respectively (Table 2; Noutoshi et al., 2012c,d,e,f).

A common feature of Imprimatin A and Imprimatin B compounds is that they only prime plants for enhanced defense reactions and cannot directly induce immune responses (Noutoshi et al., 2012e,f ). Application of each of these compounds increases levels of endogenous SA and decreases levels of the inactive SA metabolite SAG suggesting they inhibit SAGTs (Noutoshi et al., 2012e,f). Supporting this view, single and double knockout mutants of the Arabidopsis SAGT genes UGT74F1 and UGT76B1 showed increased disease resistance and free SA levels and resemble in this respect wild-type Arabidopsis plants treated with Imprimatins $A_{1}, A_{2}, A_{3}, B_{1}$, or $B_{2}$ (Noutoshi et al., 2012e). The enzymatic activities of UGT74F1 and UGT76B1 were also blocked in vitro by each of these Imprimatins at concentrations effective for immune priming. These results suggest that Imprimatin A and -B representatives have a unique mode-of-action in defense priming and specifically inhibit SAGTs (Noutoshi et al., 2012e,f). 
Table 2 | Imprimatins.

\begin{tabular}{|c|c|c|}
\hline Main type & Common name & Systematic name \\
\hline \multirow[t]{5}{*}{ Imprimatin A } & Imprimatin $A_{1}$ & $\begin{array}{l}\text { 2-[(E)-2-(2-bromo-4-hydroxy-5- } \\
\text { methoxyphenyl)ethenyl] }\end{array}$ \\
\hline & & quinolin-8-ol) \\
\hline & Imprimatin $A_{2}$ & 7-chloro-2-[(E)-2- (4-nitrophenyl)ethenyl] \\
\hline & & 4H-3,1-benzoxazin-4-one) \\
\hline & Imprimatin $A_{3}$ & 4-[(E)-2-(quinolin-2-yl)ethenyl]phenol) \\
\hline \multirow[t]{3}{*}{ Imprimatin B } & Imprimatin $\mathrm{B}_{1}$ & 2-(3-(2-furyl)-3-phenylpropyl) \\
\hline & & benzo[c]azoline-1,3-dione) \\
\hline & Imprimatin $\mathrm{B}_{2}$ & 3-(2-furyl)-3-phenylpropylamine) \\
\hline \multirow[t]{6}{*}{ Imprimatin C } & Imprimatin $\mathrm{C}_{1}$ & [(E)-[1-amino-2-(2-oxopyrrolidin-1- \\
\hline & & yl)ethylidene]amino] \\
\hline & & 4-chlorobenzoate) \\
\hline & Imprimatin $\mathrm{C}_{2}$ & [(E)-[1-amino-2-(2-oxopyrrolidin-1- \\
\hline & & yl)ethylidene]amino]3,4- \\
\hline & & dichlorobenzoate) \\
\hline
\end{tabular}

Two members of class $C$ of Imprimatins, $C_{1}$ and $C_{2}$, were found to be SA analogs, as they activate downstream SA signaling steps and induce expression of known SA-responsive genes. However, their defense-inducing activity is weaker than that of SA. Further structure-function analyses suggested that these compounds may be converted in Arabidopsis to 4-chlorobenzoic acid and 3,4chlorobenzoic acid, which can mimic the defense-related effects of Imprimatins C1 and C2 (Noutoshi et al., 2012c).

\section{SULFONAMIDES}

\section{SULFANILAMIDES}

In order to identify small molecules that reduce susceptibility of Arabidopsis to virulent P. syringae, a small collection of 200 molecules from the LATCA library (Library of Active Compounds in Arabidopsis; Zhao et al., 2007) was screened for candidates that reduce cotyledon bleaching in liquid grown seedlings. $P$. syringae induced bleaching of Arabidopsis cotyledons is a robust disease symptom that develops within 4-5 days post-inoculation with this pathogen (Schreiber et al., 2008). Among other candidates, the sulfanilamide compounds, sulfamethoxazole (Smex), sulfadiazine (Sdiz), and sulfapyridine (Spyr) were found to reduce this bleaching phenotype. Although, sulfanilamides have been widely used as antibiotics, the authors showed that these three candidates did not directly reduce bacterial viability and growth at concentrations that suppress their virulence. Thus, these compounds seem to act by inducing plant immune responses (Schreiber et al., 2008).

Sulfamethoxazole was found to be the most potent one of the three identified sulfanilamides. Smex can prevent cotyledon bleaching at a concentration of $100 \mathrm{uM}$. Interestingly, Smex does not induce PR1 expression and is active in npr1 mutants. Thus, Smex is likely to induce defense mechanisms unrelated to the canonical SA defense pathway. Smex-mediated disease protection is also independent from JA, ET, and ABA signaling and does not require an oxidative burst (Schreiber and Desveaux, 2008; Schreiber et al., 2008).

Sulfanilamides are structural analogues of $p$-aminobenzoic acid (PABA), which can inhibit dihydropteroate synthase, an enzyme that catalyzes an important step in the folate biosynthetic pathway. Smex-mediated inhibition of folate biosynthesis may induce plant defense mechanism independently from PR1 expression (Schreiber et al., 2008, 2012). A screen performed by the same lab to identify compounds that protect Arabidopsis against the fungal pathogen Fusarium graminearum resulted, besides Smex, in the identification of the indole alkaloid gramine as a plant defense inducer. Both gramine and Smex reduced severity of $F$. graminearum infection in wheat as well (Schreiber et al., 2011).

\section{OTHER SULFONAMIDES}

Noutoshi et al. (2012a), additional sulfonamide compounds were also reported to induce disease resistance in plants. By using the same chemical screening strategy that was used for Imprimatins, chemical libraries representing 2677 bioactive molecules and small natural compounds were screened to identify immune-priming molecules. Four different sulfonamide compounds, sulfameter (SFM), sulfamethoxypyridazine (SMP), sulfabenzamide (SBA), and sulfachloropyridazine (SCP) were identified in this screening and further characterized. They increased the occurrence of cell death of Arabidopsis suspension cell cultures infected by an avirulent $P$. syringae strain and were classified as immunepriming compounds. However, unlike Smex, these compounds can induce PR1 gene expression and, unlike Imprimatin A or B representatives, they do not inhibit SAGTs (Noutoshi et al., 2012a).

\section{DIURETICS}

Diuretics are pharmaceutical drugs that are widely used in clinical medicine, especially to treat hypertensive and oedematous states (Plant, 2003). Three diuretics, 3-(butylamino)-4-phenoxy5-sulfamoylbenzoic acid (Bumetanide), 3-benzyl-1,1-dioxo-6(trifluoromethyl)-3,4dihydro-2H-1,2,4-benzothiadiazine-7-sulfo namide (Bendroflumethiazide) and 4-chloro- $N$-(2,6-dimethyl1-piperidyl)-3-sulfamoyl-benzamide (Clopamide; McNeil et al., 1987; Breyer and Jacobson, 1990; Pacifici, 2012) were identified as plant immune-priming compounds through the screening of a chemical library of 2000 known bioactive compounds (Noutoshi et al., 2012b). They stimulate pathogen-induced cell death in Arabidopsis in a concentration-dependent manner. In Arabidopsis they can enhance disease resistance to both avirulent and virulent $P$. syringae strains. Effects of $100 \mathrm{uM}$ diuretic on defense induction are comparable to those triggered by $50 \mathrm{uM} \mathrm{SA}$ and they do not directly inhibit bacterial growth up to concentration of $200 \mathrm{uM}$. Application of these diuretics significantly decreases the growth of avirulent bacteria compared to mock treatment and mediates enhanced $P R 1$ gene expression after infection with $P$. syringae. These compounds potentiate disease resistance by enhancing plant defense responses, but, unlike SA and its analogs, do not induce PR1 expression in the absence of pathogen infection (Noutoshi et al., 2012b).

Diuretics exhibit pharmacological effects in humans by acting on proteins of the SLC12A family, which are sodium-coupled chloride co-transporters that are located along the renal tubule of 
the kidney nephron. Diuretics inhibit these co-transporters by binding to their $\mathrm{Cl}^{-}$binding site (Breyer and Jacobson, 1990; Gamba, 2005). The Arabidopsis genome encodes only a single protein closely related to SLC12A, At1g30450 (AtCCC1). Thus, diuretics-triggered defense priming may be mediated via AtCCC1. However, no results regarding this possible role of AtCCC1 have been reported.

Interestingly, diuretics contain a sulfonamide moiety similar to those identified in the defense-inducing sulfanilamide compounds sulfamethoxazole, sulfadiazine, and sulfapyridine (Schreiber et al., 2008). Both diuretics and sulfanilamides can decrease bacterial growth in planta. The presence of sulfonamide moieties seems to be essential for their ability to induce defense reactions, as diuretics without sulfonamide groups do not exhibit this activity (Schreiber et al., 2008; Noutoshi et al., 2012b). Further studies with diuretics and sulfanilamides are needed to uncover their modes-of-action.

\section{ADIPIC ACID DERIVATIVES}

In order to identify chemical mixtures that can delay senescence and induce immunity in plants, various mixtures of adipic acid monoethyl ester derivatives were tested. Application of a mixture of furfurylamine and 1,2,3,4-tetra-O-acetyl- $\beta$-D-glucopy-ranose (FGA) increased chlorophyll content, cell wall sugar content and delayed the chlorophyll degrading rate along with senescence in tomato and pepper (Flors et al., 2001). FGA also increased PAL activity as well as the concentration of flavonoids and phenolic compounds and strengthened plant immunity against various different pathogens such as Phytophthora citrophthora and Altemaria solani in tomato (Solanum lycopersicum L.) as well as Alternaria solani in pepper (Capsicum annuum L.; Flors etal., 2001). Individual application of three novel amides of adipic acid, 5carbamoil ethyl pentanoate (N1), 5-(2-furfurylmethylcarbamoil) ethyl pentanoate (N2) and 5-(3-aminopropylcarbamoil) ethyl pentanoate (N3) was shown to strongly induce resistance against Alternaria solani in pepper. However, many other adipic acid derivatives were most effective when used as a mixture (Flors etal., 2003a,b). Although these chemicals reduced pathogen growth in their hosts, many of them did not show any direct antimicrobial effect to pathogens and, therefore, likely induce plant immune responses (Flors etal., 2001, 2003a,b, 2004). However, the mode-of-action underlying this function remains unresolved.

\section{JASMONIC ACID ANALOGS}

Jasmonic acid and its methylester, methyl-jasmonate (MeJA), are important members of the family of jasmonates which are biologically active fatty-derived cyclopentanones, that are broadly present in the plant kingdom. They are synthesized rapidly by the octadecanoid (and possibly hexadecanoid) biosynthesis pathways upon pathogen or insect attack and activate defense responses (Howe, 2010; Wasternack and Hause, 2013). Jasmonates are known to control stress responses against nectrotrophic pathogens, herbivores and wounding, but are also known to perform various important roles in plant development related to leaf senescence, growth inhibition and floral development (He et al., 2002; Balbi and Devoto, 2008; Zhang and Turner, 2008; Oh et al., 2013; Santino et al., 2013).
Upon synthesis, JA can either be metabolized to MeJA or conjugated to L-isoleucine leading to jasmonoyl-isoleucine (JA-Ile), which is an active form of JA (Svoboda and Boland, 2010; Pieterse et al., 2012).

Together with Jasmonate ZIM-domain (JAZ)-type transcriptional repressors, the F-box protein Coronatine Insensitive1 (COI1) functions as JA-Ile receptors. Recruitment of JAZ proteins into COI1-containing SKP1-Cullin-F-box (SCFCOI1) complexes results in proteasome-mediated degradation of these transcriptional repressors. Consequently expression of a large number of JA-responsive genes is de-repressed and defense responses are activated (Browse, 2009; Pieterse et al., 2012; Monte et al., 2014). Jasmonates typically promote defense responses against necrotrophic microbial pathogens. For example, exogenous application of JA or MeJA was shown to protect barley against Erysiphe graminis f.sp. hordei (Schweizer et al., 1993). In Arabidopsis, MeJA up-regulates transcript levels of the PDF1.2 gene family along with 100s of additional genes (Schenk et al., 2000; Jung et al., 2007; Scranton et al., 2013) and enhances resistance to various necrotrophic pathogens, such as the fungi Alternaria brassicicola and Botrytis cinerea (Thomma et al., 1998; Seo et al., 2001; Rowe et al., 2010).

Systematic structural modifications of JA revealed the minimal structural requirements required for its bioactivity allowing for the synthesis of JA-mimics (Svoboda and Boland, 2010). The synthetic JA mimic coronalon (2-[(6-ethyl-1-oxo-indane-4carbonyl)-amino]-3-methyl-pentanoic acid methyl ester) mediated induction of stress responses in various plant species (Schüler et al., 2004). In addition, coronalon and its unsubstituted form (1-oxo-indanoyl-L-isoleucine methyl ester) increased levels of nicotine and trypsin proteinase inhibitors which are known MeJAactivated defense products in $N$. attenuata. They also triggered transcriptional up-regulation of the majority of genes that are known to be responsive to MeJA (Pluskota et al., 2007). The compound 1-oxo-indanoyl-L-isoleucine methyl ester was also shown to enhance activity of defense-related enzymes such as PAL or peroxidases and to induce resistance against downy mildew (Deepak et al., 2007). Additional synthetic JA mimics were shown to induce jasmonate signaling and immune responses in various plant species (Krumm etal., 1995; Fliegmann et al., 2003; Pluskota et al., 2007), However, none of these compounds were studied at the molecular level and nothing is known about their modes-of-action.

\section{CONCLUSIONS AND PERSPECTIVES}

In this review article we have provided an overview of the discovery and functional characteristics of synthetic elicitors as well as their potential for basic research and crop protection. In our opinion, three major observations stand out.

(1) The vast majority of known synthetic elicitors belongs to the large group of functional SA analogs and mimics roles of this messenger molecule in defense induction. Many of these compounds are structurally related to SA. This strong trend may be partially due to a bias in the used compound screening strategies, most of which were based on the use of known SA-triggered immune responses as an indicator of defense induction. However, the dominance of functional SA analogs 
among known synthetic elicitors may also reflect that the SAresponse pathway is particularly enriched for drug-able targets (which often have natural ligand binding pockets) and may involve more than just one type of SA receptor. This is consistent with the fact that responses triggered by different SA analogs do often not fully overlap and are partly unique. Thus, many functional SA analogs may constitute selective SA agonists, each of which interferes in a distinct manner with natural SA targets.

(2) Synthetic elicitors can be successfully applied in crop protection. Several examples illustrate the utility of plant immunestimulants or -inducers in agriculture. Most likely more examples will follow, providing attractive alternatives to conventional biocidal agrochemicals.

(3) Synthetic elicitors can also serve as potent tools in basic research approaches expanding our knowledge of plant immunity. A particularly prominent example highlighting their potency in this respect is the role of INA in the discovery of NPR1 as a central regulator of SA-dependent immune responses.

While additional screens for synthetic elicitors that are more potent and possibly distinct from those that are known are desirable, a rich arsenal of interesting plant defense-inducing compounds is already at hand. What is missing at this point, is a comprehensive systematic comparison of their functional characteristics in a single plant system, such as Arabidopsis. We anticipate specific interactions of many of these compounds with the plant immune system to define distinct "points of reference," that can be probed and further examined with each compound. A next critical step will be the identification of direct synthetic elicitor targets and their roles in plant defense. This may lead to the discovery of so far unknown components of the plant immune system and reveal novel regulatory interactions controlling plant defense reactions. Furthermore, innovative screening designs are needed to complement the set of available compounds. A greater diversity of synthetic elicitors will not only be beneficial for basic research, but may also be necessary for the design of innovative multifunctional crop protectants that stimulate multiple aspects of the plant defense system and can provide resistance against a broader spectrum of plant pathogens.

\section{ACKNOWLEDGMENTS}

We thank Mercedes Schroeder (UC-Riverside) for critical reading of the manuscript as well as both reviewers and the editor of this manuscript for valuable input. Yasemin Bektas was supported by the Turkish Republic Ministry of National Education.

\section{REFERENCES}

Abramovitch, R. B., and Martin, G. B. (2004). Strategies used by bacterial pathogens to suppress plant defenses. Curr. Opin. Plant Biol. 7, 356-364. doi: 10.1016/j.pbi.2004.05.002

An, C., and Mou, Z. (2014). "Salicylic acid and defense responses in plants," in Phytohormones: A Window to Metabolism, Signaling and Biotechnological Applications, eds L.-S. P. Tran and S. Pal (New York: Springer Science and Business Media).

Balbi, V., and Devoto, A. (2008). Jasmonate signalling network in Arabidopsis thaliana: crucial regulatory nodes and new physiological scenarios. New Phytol. 177, 301-318. doi: 10.1111/j.1469-8137.2007.02292.x

Beckers, G. J., and Conrath, U. (2007). Priming for stress resistance: from the lab to the field. Curr. Opin. Plant Biol. 10, 425-431. doi: 10.1016/j.pbi.2007.06.002
Beckers, G. J., Jaskiewicz, M., Liu, Y., Underwood, W. R., He, S. Y., Zhang, S., et al. (2009). Mitogen-activated protein kinases 3 and 6 are required for full priming of stress responses in Arabidopsis thaliana. Plant Cell 21, 944-953. doi: $10.1105 /$ tpc. 108.062158

Bhattarai, K. K., Atamian, H. S., Kaloshian, I., and Eulgem, T. (2010). WRKY72-type transcription factors contribute to basal immunity in tomato and Arabidopsis as well as gene-for-gene resistance mediated by the Tomato R Gene Mi-1. Plant J. 63, 229-240. doi: 10.1111/j.1365-313X.2010.04232.x

Blackwell, H. E., and Zhao, Y. (2003). Chemical genetic approaches to plant biology. Plant Physiol. 133, 448-455. doi: 10.1104/pp.103.031138

Branca, C., Plazzi, V., Marina, V., Bordi, F., Fracassini, D. S., and Nello, B. (1975) Auxin-like activity of 1,2-benzisothiazole derivatives. Phytochemistry 14, 25452550. doi: 10.1016/0031-9422(75)85221-6

Breyer, J., and Jacobson, H. R. (1990). Molecular mechanisms of diuretic agents. Annu. Rev. Med. 41, 265-275. doi: 10.1146/annurev.me.41.020190.001405

Browse, J. (2009). Jasmonate passes muster: a receptor and targets for the defense hormone. Annu. Rev. Plant Biol. 60, 183-205. doi: 10.1146/annurev.arplant.043008.092007

Brozek, V., Dias, L. M., Hadano, H., Münks, K. W., Sawada, H., Sirven, C., et al. (2012). Use of Isothiazolecarboxamides to Create Latent Host Defenses in a Plant. World Patents, WO 2012084858 A3.

Camoutsis, C., Geronikaki, A., Ciric, A., Soković, M., Zoumpoulakis, P., and Zervou, M. (2010). Sulfonamide-1,2,4-thiadiazole derivatives as antifungal and antibacterial agents: synthesis, biological evaluation, lipophilicity, and conformational studies. Chem. Pharm. Bull. (Tokyo) 58, 160-167. doi: 10.1248/cpb.58.160

Cao, H., Bowling, S. A., Gordon, A. S., and Dong, X. (1994). Characterization of an Arabidopsis mutant that is nonresponsive to inducers of systemic acquired resistance. Plant Cell Online 6, 1583-1592. doi: 10.1105/tpc.6.11.1583

Cao, H., Glazebrook, J., Clarke, J. D., Volko, S., and Dong, X. (1997). The Arabidopsis NPR1 gene that controls systemic acquired resistance encodes a novel protein containing ankyrin repeats. Cell 88, 57-63. doi: 10.1016/S0092-8674(00)81858-9

Chamnongpol, S., Willekens, H., Langebartels, C., Van Montagu, M., Inzé, D., and Van Camp, W. (1996). Transgenic tobacco with a reduced catalase activity develops necrotic lesions and induces pathogenesis-related expression under high light. Plant J. 10, 491-503. doi: 10.1046/j.1365-313X.1996.10030491.x

Chaudhary, S., Chattopadhyay, P., Wahi, A. K., Didel, M., and Dahiya, V. (2010). Synthesis and study of antibacterial and antifungal activity of novel 2-(5-substituted methylamino-1,3,4-thiadiazol-2yl)phenols. J. Chem. Pharm. Res. 2, 47-52.

Chen, Z., and Klessig, D. F. (1991). Identification of a soluble salicylic acid-binding protein that may function in signal transduction in the plant disease-resistance response. Proc. Natl. Acad. Sci. U.S.A. 88, 8179-8183. doi: 10.1073/pnas.88.18.8179

Chen, Z., Malamy, J., Henning, J., Conrath, U., Sánchez-Casas, P., Silva, H., et al. (1995). Induction, modification, and transduction of the salicylic acid signal in plant defense responses. Proc. Natl. Acad. Sci. U.S.A. 92, 4134-4137. doi: 10.1073/pnas.92.10.4134

Chen, Z., Ricigliano, J. W., and Klessig, D. F. (1993). Purification and characterization of a soluble salicylic acid-binding protein from tobacco. Proc. Natl. Acad. Sci. U.S.A. 90, 9533-9537. doi: 10.1073/pnas.90.20.9533

Chisholm, S. T., Coaker, G., Day, B., and Staskawicz, B. J. (2006). Host-microbe interactions: shaping the evolution of the plant immune response. Cell 124, 803814. doi: 10.1016/j.cell.2006.02.008

Conrath, U. (2006). Systemic acquired resistance. Plant Signal. Behav. 1, 179-184. doi: $10.4161 /$ psb.1.4.3221

Conrath, U. (2011). Molecular aspects of defence priming. Trends Plant Sci. 16, 524-531. doi: 10.1016/j.tplants.2011.06.004

Conrath, U., Beckers, G. J., Flors, V., García-Agustín, P., Jakab, G., Mauch, F., et al. (2006). Priming: getting ready for battle. Mol. Plant Microbe Interact. 19, 1062-1071. doi: 10.1094/MPMI-19-1062

Conrath, U., Chen, Z., Ricigliano, J. R., and Klessig, D. F. (1995). Two inducers of plant defense responses, 2,6-dichloroisonicotinec acid and salicylic acid, inhibit catalase activity in tobacco. Proc. Natl. Acad. Sci. U.S.A. 92, 7143-7147. doi: 10.1073/pnas.92.16.7143

Conrath, U., Pieterse, C. M., and Mauch-Mani, B. (2002). Priming in plant-pathogen interactions. Trends Plant Sci. 7, 210-216. doi: 10.1016/S1360-1385(02)02244-6

De, A. (1981). Biologically active 1,2-benzisothiazole derivatives. Prog. Med. Chem. $18,117-133$

Dean, P. (2005). "Computer-aided design of small molecules for chemical genomics," in Chemical Genomics, ed. E. Zanders (Totowa, NJ: Humana Press). 
Deepak, S., Niranjan-Raj, S., Shailasree, S., Kini, R. K., Boland, W., Shetty, H. S., et al. (2007). Induction of resistance against downy mildew pathogen in pearl millet by a synthetic jasmonate analogon. Physiol. Mol. Plant Pathol. 71, 96-105. doi: 10.1016/j.pmpp.2007.12.003

Delaney, T. P., Friedrich, L., and Ryals, J. A. (1995). Arabidopsis signal transduction mutant defective in chemically and biologically induced disease resistance. Proc. Natl. Acad. Sci. U.S.A. 92, 6602-6606. doi: 10.1073/pnas.92.14.6602

Delaney, T. P., Uknes, S., Vernooij, B., Friedrich, L., Weymann, K., Negrotto, D., et al. (1994). A central role of salicylic acid in plant disease resistance. Science 266, 1247-1250. doi: 10.1126/science.266.5188.1247

Dodds, P. N., and Rathjen, J. P. (2010). Plant immunity: towards an integrated view of plant-pathogen interactions. Nat. Rev. Genet. 11, 539-548. doi: $10.1038 / \mathrm{nrg} 2812$

Dong, X. (2004). NPR1, all things considered. Curr. Opin. Plant Biol. 7, 547-552. doi: 10.1016/j.pbi.2004.07.005

Du, H., and Klessig, D. F. (1997). Identification of a soluble, high-affinity salicylic acid-binding protein in tobacco. Plant Physiol. 113, 1319-1327.

Durner, J., and Klessig, D. F. (1995). Inhibition of ascorbate peroxidase by salicylic acid and 2,6-dichloroisonicotinic acid, two inducers of plant defense responses. Proc. Natl. Acad. Sci. U.S.A. 92, 11312-11316. doi: 10.1073/pnas.92.24.11312

Durrant, W. E., and Dong, X. (2004). Systemic acquired resistance. Annu. Rev. Phytopathol. 42, 185-209. doi: 10.1146/annurev.phyto.42.040803.140421

Elmore, J. M., Lin, Z. J., and Coaker, G. (2011). Plant NB-LRR signaling: upstreams and downstreams. Curr. Opin. Plant Biol. 14, 365-371. doi: 10.1016/j.pbi.2011.03.011

Eulgem, T. (2005). Regulation of the Arabidopsis defense transcriptome. Trends Plant Sci. 10, 71-78. doi: 10.1016/j.tplants.2004.12.006

Fan, Z., Shi, Z., Zhang, H., Liu, X., Bao, L., Ma, L., et al. (2009). Synthesis and biological activity evaluation of 1,2,3-thiadiazole derivatives as potential elicitors with highly systemic acquired resistance. J. Agric. Food Chem. 57, 4279-4286. doi: $10.1021 /$ jf8031364

Fliegmann, J., Schüler, G., Boland, W., Ebel, J., and Mithöfer, A. (2003). The role of octadecanoids and functional mimics in soybean defense responses. Biol. Chem. 384, 437-446. doi: 10.1515/BC.2003.049

Flor, H. H. (1971). Current status of the gene for gene concept. Annu. Rev. Phytopathol. 9, 275-296. doi: 10.1146/annurev.py.09.090171.001423

Flors, V., Miralles, C., Cerezo, M., González-Bosch, C., and García-Agustín, P. (2001). Effect of a novel chemical mixture on senescence processes and plantfungus interaction in solanaceae plants. J. Agric. Food Chem. 49, 2569-2575. doi: $10.1021 /$ jf000068y

Flors, V., Miralles, M. C., González-Bosch, C., Carda, M., and García-Agustín, P. (2003a). Induction of protection against the necrotrophic pathogens Phytophthora citrophthora and Alternaria solani in Lycopersicon esculentum Mill. by a novel synthetic glycoside combined with amines. Planta 216, 929-938. doi: 10.1007/s00425-002-0945-8

Flors, V. C., Miralles, C., González-Bosch, C., Carda, M., and García-Agustí, N. P. (2003b). Three novel synthetic amides of adipic acid protect Capsicum anuum plants against the necrotrophic pathogen Alternaria solani. Physiol. Mol. Plant Pathol. 63, 151-158. doi: 10.1016/j.pmpp.2003.10.007

Flors, V., Miralles, M. C., Varas, E., Company, P., González-Bosch, C., and García-Agustín, P. (2004). Effect of analogues of plant growth regulators on in vitro growth of eukaryotic plant pathogens. Plant Pathol. 53, 58-64. doi: 10.1111/j.1365-3059.2004.00942.x

Forouhar, F., Yang, Y., Kumar, D., Chen, Y., Fridman, E., Park, S. W., et al. (2005). Structural and biochemical studies identify tobacco SABP2 as a methyl salicylate esterase and implicate it in plant innate immunity. Proc. Natl. Acad. Sci. U.S.A 102, 1773-1778. doi: 10.1073/pnas.0409227102

Friedrich, L., Lawton, K., Ruess, W., Masner, P., Specker, N., Rella, M. G., et al. (1996). A benzothiadiazole derivative induces systemic acquired resistance in tobacco. Plant J. 10, 61-70. doi: 10.1046/j.1365-313X.1996.10010061.x

Fu, Z. Q., and Dong, X. (2013). Systemic acquired resistance: turning local infection into global defense. Annu. Rev. Plant Biol. 64, 839-863. doi: 10.1146/annurevarplant-042811-105606

Fu, Z. Q., Yan, S., Saleh, A., Wang, W., Ruble, J., Oka, N., et al. (2012). NPR3 and NPR4 are receptors for the immune signal salicylic acid in plants. Nature 486, 228-232. doi: 10.1038/nature11162

Gamba, G. (2005). Molecular physiology and pathophysiology of electroneutral cation-chloride cotransporters. Physiol. Rev. 85, 423-493. doi: 10.1152/physrev.00011.2004
Gianinazzi, S., and Kassanis, B. (1974). Virus resistance induced in plants by polyacrylic acid. J. Gen. Virol. 23, 1-9. doi: 10.1099/0022-1317-23-1-1

Giannella, M., Gualtieri, F., and Melchiorre, C. (1971). Benzisoxazole and benzisothiazole analogs of auxin. Phytochemistry 10, 539-544. doi: 10.1016/S00319422(00)94694-6

Glazebrook, J. (2001). Genes controlling expression of defense responses in Arabidopsis-2001 status. Curr. Opin. Plant Biol. 4, 301-308. doi: 10.1016/S13695266(00)00177-1

Glazebrook, J. (2005). Contrasting mechanisms of defense against biotrophic and necrotrophic pathogens. Annu. Rev. Phytopathol. 43, 205-227. doi: 10.1146/annurev.phyto.43.040204.135923

Glazebrook, J., Chen, W., Estes, B., Chang, H. S., Nawrath, C., Metraux, J. P., et al. (2003). Topology of the network integrating salicylate and jasmonate signal transduction derived from global expression phenotyping. Plant J. 34, 217-228. doi: 10.1046/j.1365-313X.2003.01717.x

Goellner, K., and Conrath, U. (2008). Priming: it's all the world to induced disease resistance. Eur. J. Plant Pathol. 121, 233-242. doi: 10.1007/s10658-007-9251-4

Gómez-Gómez, L., and Boller, T. (2002). Flagellin perception: a paradigm for innate immunity. Trends Plant Sci. 7, 251-256. doi: 10.1016/S1360-1385(02)02261-6

Görlach, J., Volrath, S., Knauf-Beiter, G., Hengy, G., Beckhove, U., Kogel, K.-H., et al. (1996). Benzothiadiazole, a novel class of inducers of systemic acquired resistance, activates gene expression and disease resistance in wheat. Plant Cell 8 , 629-643. doi: 10.1105/tpc.8.4.629

Han, D. Y., Coplin, D. L., Bauer, W. D., and Hoitink, H. A. J. (2000). A rapid bioassay for screening rhizosphere microorganisms for their ability to induce systemic resistance. Phytopathology 90, 327-332. doi: 10.1094/PHYTO.2000.90.4.327

He, Y., Fukushige, H., Hildebrand, D. F., and Gan, S. (2002). Evidence supporting a role of jasmonic acid in Arabidopsis leaf senescence. Plant Physiol. 128, 876-884. doi: 10.1104/pp.010843

Hijwegen, T., and Verhaar, M. A. (1993). Induced resistance to Peronospora parasitica in red cabbage. Neth. J. Plant Pathol. 99, 103-107. doi: 10.1007/BF03041400

Holub, E. B. (2008). Natural history of Arabidopsis thaliana and oomycete symbioses. Eur. J. Plant Pathol. 122, 91-109. doi: 10.1007/s10658-008-9286-1

Howe, G. (2010). "Jasmonates," in Plant Hormones: Biosynthesis, Signal Transduction, Action!, 3rd Edn, ed. P. J. Davies (Dordrecht: Springer).

Iwata, M. (2001). Probenazole - a plant defence activator. Pesticide Outlook 12, 28-31. doi: 10.1039/b100805f

Jaskiewicz, M., Conrath, U., and Peterhänsel, C. (2011). Chromatin modification acts as a memory for systemic acquired resistance in the plant stress response. EMBO Rep. 12, 50-55. doi: 10.1038/embor.2010.186

Jones, J. D., and Dangl, J. L. (2006). The plant immune system. Nature 444, 323-329. doi: 10.1038/nature05286

Jung, C., Lyou, S. H., Yeu, S., Kim, M. A., Rhee, S., Kim, M., et al. (2007). Microarraybased screening of jasmonate-responsive genes in Arabidopsis thaliana. Plant Cell Rep. 26, 1053-1063. doi: 10.1007/s00299-007-0311-1

Kassanis, B., and White, R. F. (1975). Polyacrylic acid -induced resistance to tobacco mosaic virus in Tobacco cv. Xanthi. Ann. Appl. Biol. 79, 215-220. doi: 10.1111/j.1744-7348.1975.tb01535.x

Katagiri, F. (2004). A global view of defense gene expression regulation-a highly interconnected signaling network. Curr. Opin. Plant Biol. 7, 506-511. doi: 10.1016/j.pbi.2004.07.013

Katz, V. A., Thulke, O. U., and Conrath, U. (1998). A benzothiadiazole primes parsley cells for augmented elicitation of defense responses. Plant Physiol. 117, 1333-1339. doi: 10.1104/pp.117.4.1333

Kauss, H., Theisinger-Hinkel, E., Mindermann, R., and Conrath, U. (1992). Dichloroisonicotinic and salicylic acid, inducers of systemic acquired resistance, enhance fungal elicitor responses in parsley cells. Plant J. 2, 655-660. doi: 10.1111/j.1365-313X.1992.tb00134.x

Kharb, R., Kaur, P., Sharma, P. C., and Yar, M. S. (2011). Significance of thiadiazole derivatives as antimicrobial agents. Int. J. Res. Pharm. Biomed. Sci. 2, 1520-1540.

Knoth, C., and Eulgem, T. (2014). "High-throughput screening of small-molecule libraries for inducers of plant defense responses," in Plant Chemical Genomics, eds G. R. Hicks and S. Robert (New York: Humana Press).

Knoth, C., Ringler, J., Dangl, J. L., and Eulgem, T. (2007). Arabidopsis WRKY70 is required for full RPP4-mediated disease resistance and basal defense against Hyaloperonospora parasitica. Mol. Plant Microbe Interact. 20, 120-128. doi: 10.1094/MPMI-20-2-0120 
Knoth, C., Salus, M. S., Girke, T., and Eulgem, T. (2009). The synthetic elicitor 3,5-dichloroanthranilic acid induces NPR1-dependent and NPR1-independent mechanisms of disease resistance in Arabidopsis. Plant Physiol. 150, 333-347. doi: $10.1104 /$ pp.108.133678

Kohler, A., Schwindling, S., and Conrath, U. (2002). Benzothiadiazole-induced priming for potentiated responses to pathogen infection, wounding, and infiltration of water into leaves requires the NPR1/NIM1 gene in Arabidopsis. Plant Physiol. 128, 1046-1056. doi: 10.1104/pp.010744

Kombrink, E., and Somssich, I. E. (1997). "Pathogenesis-related proteins and plant defense," in Plant Relationships, eds G. Carroll and P. Tudzynski (Berlin: SpringerVerlag).

Krumm, T., Bandemer, K., and Boland, W. (1995). Induction of volatile biosynthesis in the lima bean (Phaseolus lunatus) by leucine- and isoleucine conjugates of 1 Oxo- and 1-hydroxyindan-4-carboxylic acid: evidence for amino acid conjugates of jasmonic acid as intermediates in the octadecanoid signalling pathway. FEBS Lett. 377, 523-529. doi: 10.1016/0014-5793(95)01398-9

Kuc, J. (1982). Induced immunity to plant disease. Bioscience 32, 854-860. doi: $10.2307 / 1309008$

Kumar, D., and Klessig, D. F. (2003). High-affinity salicylic acid-binding protein 2 is required for plant innate immunity and has salicylic acid-stimulated lipase activity. Proc. Natl. Acad. Sci. U.S.A. 100, 16101-16106. doi: 10.1073/pnas.0307162100

Kunz, W., Schurter, R., and Maetzke, T. (1997). The chemistry of benzothiadiazole plant activators. Pestic. Sci. 50, 275-282. doi: 10.1002/(SICI)10969063(199708)50:4<275::AID-PS593>3.0.CO;2-7

Kunz, W., Staub, T., Metraux, J.-P., Hoegerle, K., Nyfeler, R., and Ahl, P. (1988). A method for protecting plants against diseases. European Patent, EP 0268775 A1.

Langcake, P., and Wickins, S. G. A. (1975a). Studies on the action of the dichlorocyclopropanes on the host-parasite relationship in the rice blast disease. Physiol. Plant Pathol. 7, 113-126. doi: 10.1016/0048-4059(75)90002-8

Langcake, P., and Wickins, S. G. A. (1975b). Studies on the mode of action of the dichlorocyclopropane fungicides : effects of 2,2-dichloro- 3,3-dimethyl cyclopropane carboxylic acid on the growth of Piricularia oryzae cav. J. Gen. Microbiol. 88, 295-306. doi: 10.1099/00221287-88-2-295

Lawton, K. A., Friedrich, L., Hunt, M., Weymann, K., Delaney, T., Kessmann, H., et al. (1996). Benzothiadiazole induces disease resistance in Arabidopsis by activation of the systemic acquired resistance signal transduction pathway. Plant J. 10, 71-82. doi: 10.1046/j.1365-313X.1996.10010071.x

Lee, S., Hong, J. C., Jeon, W. B., Chung, Y. S., Sung, S., Choi, D., et al. (2009). The salicylic acid-induced protection of non-climacteric unripe pepper fruit against Colletotrichum gloeosporioides is similar to the resistance of ripe fruit. Plant Cell Rep. 28, 1573-1580. doi: 10.1007/s00299-009-0756-5

Li, J., Brader, G., and Palva, E. T. (2004). The WRKY70 transcription factor: a node of convergence for jasmonate-mediated and salicylate-mediated signals in plant defense. Plant Cell Online 16, 319-331. doi: 10.1105/tpc.016980

McNeil, J. J., Conway, E. L., Drummer, O. H., Howes, L. G., Christophidis, N., and Louis, W. J. (1987). Clopamide: plasma concentrations and diuretic effect in humans. Clin. Pharmacol. Ther. 42, 299-304. doi: 10.1038/clpt.1987.151

Metraux, J. P., Ahlgoy, P., Staub, T., Speich, J., Steinemann, A., Ryals, J., et al. (1991). "Induced systemic resistance in cucumber in response to 2,6-dichloroisonicotinic acid and pathogens," in Advances in Molecular Genetics of PlantMicrobe Interactions, Vol. 1, eds H. Hennecke and D. Verma (Dordrecht: Kluwer Academic Publishers).

Metraux, J. P., Signer, H., Ryals, J., Ward, E., Wyss-Benz, M., Gaudin, J., et al. (1990) Increase in salicylic acid at the onset of systemic acquired resistance in cucumber Science 250, 1004-1006. doi: 10.1126/science.250.4983.1004

Midoh, N., and Iwata, M. (1996). Cloning and characterization of a probenazoleinducible gene for an intracellular pathogenesis-related protein in rice. Plant Cell Physiol. 37, 9-18. doi: 10.1093/oxfordjournals.pcp.a028918

Monte, I., Hamberg, M., Chini, A., Gimenez-Ibanez, S., García-Casado, G., Porzel, A., et al. (2014). Rational design of a ligand-based antagonist of jasmonate perception. Nat. Chem. Biol. 10, 671-676. doi: 10.1038/nchembio.1575

Nakashita, H., Yasuda, M., Nishioka, M., Hasegawa, S., Arai, Y., Uramoto, M., et al. (2002a). Chloroisonicotinamide derivative induces a broad range of disease resistance in rice and tobacco. Plant Cell Physiol. 43, 823-831. doi: 10.1093/pcp/pcf097

Nakashita, H., Yoshioka, K., Yasuda, M., Nitta, T., Arai, Y., Yoshida, S., et al. (2002b). Probenazole induces systemic acquired resistance in tobacco through salicylic acid accumulation. Physiol. Mol. Plant Pathol. 61, 197-203. doi: 10.1006/pmpp.2002.0426
Nakashita, H., Yoshioka, K., Takayama, M., Kuga, R., Midoh, N., Usami, R., et al. (2001). Characterization of PBZ1, a probenazole-inducible gene, in suspension-cultured rice cells. Biosci. Biotechnol. Biochem. 65, 205-208. doi: 10.1271/bbb.65.205

Nakayama, A., Fukushima, S., Goto, S., Matsushita, A., Shimono, M., Sugano, S., et al. (2013). Genome-wide identification of WRKY45-regulated genes that mediate benzothiadiazole-induced defense responses in rice. BMC Plant Biol. 13:150. doi: 10.1186/1471-2229-13-150

Nimchuk, Z., Eulgem, T., Holt, B. F. III, and Dangl, J. L. (2003). Recognition and response in the plant immune system. Annu. Rev. Genet. 37, 579-609. doi: 10.1146/annurev.genet.37.110801.142628

Nishioka, M., Nakashita, H., Suzuki, H., Akiyama, S., Yoshida, S., and Yamaguchi, I. (2003). Induction of resistance against rice blast disease by a novel class of plant activators, pyrazolecarboxylic acid derivatives. J. Pestic. Sci. 28, 416-421. doi: 10.1584/jpestics.28.416

Nishioka, M., Nakashita, H., Yasuda, M., Yoshida, S., and Yamaguchi, I. (2005) Induction of resistance against rice bacterial leaf blight by 3-chloro-1- methyl1h-pyrazole-5-carboxylic acid. J. Pestic. Sci. 30, 47-49. doi: 10.1584/jpestics.30.47

Noutoshi, Y., Ikeda, M., Saito, T., Osada, H., and Shirasu, K. (2012a). Sulfonamides identified as plant immune-priming compounds in high-throughput chemical screening increase disease resistance in Arabidopsis thaliana. Front. Plant Sci. 3:245. doi: 10.3389/fpls.2012.00245

Noutoshi, Y., Ikeda, M., and Shirasu, K. (2012b). Diuretics prime plant immunity in Arabidopsis thaliana. PLoS ONE 7:e48443. doi: 10.1371/journal.pone.0048443

Noutoshi, Y., Jikumaru, Y., Kamiya, Y., and Shirasu, K. (2012c). ImprimatinC1, a novel plant immune-priming compound, functions as a partial agonist of salicylic acid. Sci. Rep. 2:705. doi: 10.1038/srep00705

Noutoshi, Y., Okazaki, M., Kida, T., Nishina, Y., Morishita, Y., Ogawa, T., et al. (2012d). Novel plant immune-priming compounds identified via highthroughput chemical screening target salicylic acid glucosyltransferases in Arabidopsis. Plant Cell 24, 3795-3804. doi: 10.1105/tpc.112.098343

Noutoshi, Y., Okazaki, M., and Shirasu, K. (2012e). Imprimatins A and B: novel plant activators targeting salicylic acid metabolism in Arabidopsis thaliana. Plant Signal. Behav. 7, 1715-1717. doi: 10.4161/psb.22368

Noutoshi, Y., Okazaki, M., and Shirasu, K. (2012f). Isolation and characterization of the plant immune-priming compounds imprimatin b3 and -b4, potentiators of disease resistance in Arabidopsis thaliana. Plant Signal. Behav. 7, 1526-1528. doi: $10.4161 /$ psb. 22138

Nürnberger, T., and Lipka, V. (2005). Non-host resistance in plants: new insights into an old phenomenon. Mol. Plant Pathol. 6, 335-345. doi: 10.1111/j.13643703.2005.00279.x

Ogava, M., Kadowaki, A., Yamada, T., and Kadooka, O. (2011). Applied Development of a Novel Fungicide Isotianil (Stout). R\&D Report, No. I. Takarazuka: Health \& Crop Sciences Research Laboratory, Sumitomo Chemical Co., Ltd, 1-16.

Oh, Y., Baldwin, I. T., and Galis, I. (2013). A jasmonate ZIM-domain protein najazd regulates floral jasmonic acid levels and counteracts flower abscission in Nicotiana attenuata plants. PLoS ONE 8:e57868. doi: 10.1371/journal.pone.0057868

Oostendorp, M., Kunz, W., Dietrich, B., and Staub, T. (2001). Induced disease resistance in plants by chemicals. Eur. J. Plant Pathol. 107, 19-28. doi: 10.1023/A:1008760518772

Pacifici, G. M. (2012). Clinical pharmacology of the loop diuretics furosemide and bumetanide in neonates and infants. Paediatr. Drugs 14, 233-246. doi: 10.2165/11596620-000000000-00000

Park, S. W., Kaimoyo, E., Kumar, D., Mosher, S., and Klessig, D. F. (2007). Methyl salicylate is a critical mobile signal for plant systemic acquired resistance. Science 318, 113-116. doi: 10.1126/science.1147113

Pieterse, C. M., Van Der Does, D., Zamioudis, C., Leon-Reyes, A., and Van Wees, S. C. (2012). Hormonal modulation of plant immunity. Annu. Rev. Cell Dev. Biol. 28, 489-521. doi: 10.1146/annurev-cellbio-092910-154055

Pieterse, C. M., Van Wees, S. C., Van Pelt, J. A., Knoester, M., Laan, R., Gerrits, H., et al. (1998). A novel signaling pathway controlling induced systemic resistance in Arabidopsis. Plant Cell 10, 1571-1580. doi: 10.1105/tpc.10. 9.1571

Plant, L. (2003). Clinical use of diuretics. Clin. Med. 3, 517-520. doi: 10.7861/clinmedicine.3-6-517

Pluskota, W. E., Qu, N., Maitrejean, M., Boland, W., and Baldwin, I. T. (2007). Jasmonates and its mimics differentially elicit systemic defence responses in Nicotiana attenuata. J. Exp. Bot. 58, 4071-4082. doi: 10.1093/jxb/ erm263 
Raikhel, N., and Pirrung, M. (2005). Adding precision tools to the plant biologists' toolbox with chemical genomics. Plant Physiol. 138, 563-564. doi: 10.1104/pp.104.900155

Rasmussen, J. B., Hammerschmidt, R., and Zook, M. N. (1991). Systemic induction of salicylic acid accumulation in cucumber after inoculation with Pseudomonas syringae pv syringae. Plant Physiol. 97, 1342-1347. doi: 10.1104/pp.97.4.1342

Rowe, H. C., Walley, J. W., Corwin, J., Chan, E. K., Dehesh, K., and Kliebenstein, D. J. (2010). Deficiencies in jasmonate-mediated plant defense reveal quantitative variation in Botrytis cinerea pathogenesis. PLoS Pathog. 6:e1000861. doi: 10.1371/journal.ppat.1000861

Ryals, J., Weymann, K., Lawton, K., Friedrich, L., Ellis, D., Steiner, H. Y., et al. (1997). The Arabidopsis NIM1 protein shows homology to the mammalian transcription factor inhibitor i kappa B. Plant Cell 9, 425-439. doi: 10.1105/tpc.9.3.425

Santino, A., Taurino, M., De Domenico, S., Bonsegna, S., Poltronieri, P., Pastor, V., et al. (2013). Jasmonate signaling in plant development and defense response to multiple (a)biotic stresses. Plant Cell Rep. 32, 1085-1098. doi: 10.1007/s00299013-1441-2

Sato, M., Tsuda, K., Wang, L., Coller, J., Watanabe, Y., Glazebrook, J., et al. (2010) Network modeling reveals prevalent negative regulatory relationships between signaling sectors in Arabidopsis immune signaling. PLoS Pathog. 6:e1001011. doi: 10.1371/journal.ppat.1001011

Schenk, P. M., Kazan, K., Wilson, I., Anderson, J. P., Richmond, T., Somerville, S. C., et al. (2000). Coordinated plant defense responses in Arabidopsis revealed by microarray analysis. Proc. Natl. Acad. Sci. U.S.A. 97, 11655-11660. doi: 10.1073/pnas.97.21.11655

Schreiber, K. J., Austin, R. S., Gong, Y., Zhang, J., Fung, P., Wang, P. W., et al. (2012) Forward chemical genetic screens in Arabidopsis identify genes that influence sensitivity to the phytotoxic compound sulfamethoxazole. BMC Plant Biol. 12:226 doi: 10.1186/1471-2229-12-226

Schreiber, K., Ckurshumova, W., Peek, J., and Desveaux, D. (2008). A highthroughput chemical screen for resistance to Pseudomonas syringae in Arabidopsis. Plant J. 54, 522-531. doi: 10.1111/j.1365-313X.2008.03425.x

Schreiber, K., and Desveaux, D. (2008). Message in a bottle: chemical biology of induced disease resistance in plants. Plant Pathol. J. 24, 245-268. doi: 10.5423/PPJ.2008.24.3.245

Schreiber, K. J., Nasmith, C. G., Allard, G., Singh, J., Subramaniam, R., and Desveaux, D. (2011). Found in translation: high-throughput chemical screening in Arabidopsis thaliana identifies small molecules that reduce Fusarium head blight disease in wheat. Mol. Plant Microbe Interact. 24, 640-648. doi: 10.1094/MPMI-09-10-0210

Schüler, G., Mithöfer, A., Baldwin, I. T., Berger, S., Ebel, J., Santos, J. G., et al. (2004). Coronalon: a powerful tool in plant stress physiology. FEBS Lett. 563, 17-22. doi: 10.1016/S0014-5793(04)00239-X

Schurter, R., Kunz, W., and Nyfeler, R. (1993). Process and a composition for immunizing plants against diseases. US Patent, US5190928A.

Schweizer, P., Gees, R., and Mosinger, E. (1993). Effect of jasmonic acid on the interaction of barley (Hordeum vulgare L.) with the powdery mildew Erysiphe graminis f. sp. hordei. Plant Physiol. 102, 503-511.

Scranton, M. A., Fowler, J. H., Girke, T., and Walling, L. L. (2013). Microarray analysis of tomato's early and late wound response reveals new regulatory targets for leucine aminopeptidase A. PLoS ONE 8:e77889. doi: 10.1371/journal.pone.0077889

Segonzac, C., and Zipfel, C. (2011). Activation of plant pattern-recognition receptors by bacteria. Curr. Opin. Microbiol. 14, 54-61. doi: 10.1016/j.mib.2010.12.005

Sekizawa, Y., Shimura, M., Suzuki, A., and Iwata, M. (1981). Anti-conidial germination factors induced in the presence of probenazole in infected host leaves. II. Structural elucidation of the major component (Substance B). Agric. Biol. Chem. 45, 1437-1439. doi: 10.1271/bbb1961.45.1437

Seo, H. S., Song, J. T., Cheong, J. J., Lee, Y. H., Lee, Y. W., Hwang, I., et al. (2001). Jasmonic acid carboxyl methyltransferase: a key enzyme for jasmonateregulated plant responses. Proc. Natl. Acad. Sci. U.S.A. 98, 4788-4793. doi: 10.1073/pnas.081557298

Shen, Q. H., Saijo, Y., Mauch, S., Biskup, C., Bieri, S., Keller, B., et al. (2007). Nuclear activity of MLA immune receptors links isolate-specific and basal diseaseresistance responses. Science 315, 1098-1103. doi: 10.1126/science.1136372

Shimono, M., Koga, H., Akagi, A., Hayashi, N., Goto, S., Sawada, M., et al. (2012). Rice WRKY45 plays important roles in fungal and bacterial disease resistance. Mol. Plant Pathol. 13, 83-94. doi: 10.1111/j.1364-3703.2011.00732.x
Shimono, M., Sugano, S., Nakayama, A., Jiang, C. J., Ono, K., Toki, S., et al. (2007). Rice WRKY45 plays a crucial role in benzothiadiazole-inducible blast resistance. Plant Cell 19, 2064-2076. doi: 10.1105/tpc.106.046250

Shimura, M., Mase, S., Iwata, M., Suzuki, A., Watanabe, T., Sekizawa, Y., et al. (1983). Anti-conidial germination factors induced in the presence of probenazole in infected host leaves. III. Structural elucidation of Substances A and C. Agric. Biol. Chem. 47, 1983-1989. doi: 10.1271/bbb1961.47.1983

Singh, A. K., Mishra, G., and Jyoti, K. (2011). Review on biological activities of 1, 3, 4-thiadiazole derivatives. J. App. Pharm. Sci. 5, 44-49.

Slaymaker, D. H., Navarre, D. A., Clark, D., Del Pozo, O., Martin, G. B., and Klessig, D. F. (2002). The tobacco salicylic acid-binding protein 3 (SABP3) is the chloroplast carbonic anhydrase, which exhibits antioxidant activity and plays a role in the hypersensitive defense response. Proc. Natl. Acad. Sci. U.S.A. 99, 11640-11645. doi: 10.1073/pnas.182427699

Spanu, P. D. (2012). The genomics of obligate (and nonobligate) biotrophs. Annu. Rev. Phytopathol. 50, 91-109. doi: 10.1146/annurev-phyto-081211-173024

Sticher, L., Mauch-Mani, B., and Metraux, J. P. (1997). Systemic acquired resistance. Annu. Rev. Phytopathol. 35, 235-270. doi: 10.1146/annurev.phyto.35.1.235

Stockwell, B. R. (2004). Exploring biology with small organic molecules. Nature 432, 846-854. doi: 10.1038/nature03196

Svoboda, J., and Boland, W. (2010). Plant defense elicitors: analogues of jasmonoyl-isoleucine conjugate. Phytochemistry 71, 1445-1449. doi: 10.1016/j.phytochem.2010.04.027

Tao, Y., Xie, Z., Chen, W., Glazebrook, J., Chang, H. S., Han, B., et al. (2003). Quantitative nature of Arabidopsis responses during compatible and incompatible interactions with the bacterial pathogen Pseudomonas syringae. Plant Cell 15, 317-330. doi: 10.1105/tpc.007591

Tenhaken, R., Anstätt, C., Ludwig, A., and Seehaus, K. (2001). WY-14,643 and other agonists of the peroxisome proliferator-activated receptor reveal a new mode of action for salicylic acid in soybean disease resistance. Planta 212, 888-895. doi: 10.1007/s004250000463

Tenhaken, R., and Rubel, C. (1997). Salicylic acid is needed in hypersensitive cell death in soybean but does not act as a catalase inhibitor. Plant Physiol. 115, 291-298. doi: 10.1104/pp.115.1.291

Thomma, B. P. H. J., Eggermont, K., Penninckx, I. A. M. A., Mauch-Mani, B., Vogelsang, R., Cammue, B. P. A., et al. (1998). Separate jasmonate-dependent and salicylate-dependent defense-response pathways in Arabidopsis are essential for resistance to distinct microbial pathogens. Proc. Natl. Acad. Sci. U.S.A. 95, 15107-15111. doi: 10.1073/pnas.95.25.15107

Thulke, O., and Conrath, U. (1998). Salicylic acid has a dual role in the activation of defence-related genes in parsley. Plant J. 14, 35-42. doi: 10.1046/j.1365313X.1998.00093.x

Toquin, V., Sirven, C., Assmann, L., and Sawada, H. (2012). Host Defense Inducers. Modern Crop Protection Compounds. Wiley-VCH Verlag GmbH \& Co. KGaA. doi: 10.1002/9783527644179.ch26

Trapani, G., Reho, A., Morlacchi, F., Latrofa, A., Marchini, P., Venturi, F., et al. (1985). Synthesis and antiinflammatory activity of various 1,4-benzothiazine derivatives. Farmaco Sci. 40, 369-376.

Tripathi, D., Jiang, Y. L., and Kumar, D. (2010). SABP2, a methyl salicylate esterase is required for the systemic acquired resistance induced by acibenzolar-s-methyl in plants. FEBS Lett. 584, 3458-3463. doi: 10.1016/j.febslet.2010.06.046

Tsubata, K., Kuroda, K., Yamamoto, Y., and Yasokawa, N. (2006). Development of a novel plant activator for rice diseases, Tiadinil. J. Pestic. Sci. 31, 161-162. doi: 10.1584/jpestics.31.161

Tsuda, K., Sato, M., Stoddard, T., Glazebrook, J., and Katagiri, F. (2009). Network properties of robust immunity in plants. PLoS Genet. 5:e1000772. doi: 10.1371/journal.pgen.1000772

Uknes, S., Mauch-Mani, B., Moyer, M., Potter, S., Williams, S., Dincher, S., et al. (1992). Acquired resistance in Arabidopsis. Plant Cell 4, 645-656. doi: 10.1105/tpc.4.6.645

Uknes, S., Morris, S., Vernooij, B., and Ryals, J. (1996). "The role of benzoic acid derivatives in systemic acquired resistance," in Phytochemical Diversity and Redundancy in Ecological Interactions, eds J. Romeo, J. Saunders, and P. Barbosa (New York: Springer).

Umemura, K., Satou, J., Iwata, M., Uozumi, N., Koga, J., Kawano, T., et al. (2009). Contribution of salicylic acid glucosyltransferase, OSSGT1, to chemically induced disease resistance in rice plants. Plant J. 57, 463-472. doi: 10.1111/j.1365-313X.2008.03697.x 
Vallad, G. E., and Goodman, R. M. (2004). Systemic acquired resistance and induced systemic resistance in conventional agriculture. Crop Sci. 44, 1920-1934. doi: 10.2135/cropsci2004.1920

Van Kan, J. L., Cozijnsen, T., Danhash, N., and De Wit, P. G. M. (1995). Induction of tomato stress protein mRNAs by ethephon, 2,6-dichloroisonicotinic acid and salicylate. Plant Mol. Biol. 27, 1205-1213. doi: 10.1007/BF00020894

van Wees, S. C., De Swart, E. A., Van Pelt, J. A., Van Loon, L. C., and Pieterse, C. M. (2000). Enhancement of induced disease resistance by simultaneous activation of salicylate- and jasmonate-dependent defense pathways in Arabidopsis thaliana. Proc. Natl. Acad. Sci. U.S.A. 97, 8711-8716. doi: 10.1073/pnas.130425197

Vernooij, B., Friedrich, L., Goy, P. A., Staub, T., Kessmann, H., and Ryals, J. (1995). 2,6-dicholoroisonicotinic acid-induced resistance to pathogens without the accumulation of saliciylic acid. Mol. Plant Microbe Interact. 8, 228-234. doi: 10.1094/MPMI-8-0228

Vernooij, B., Uknes, S., Ward, E., and Ryals, J. (1994). Salicylic acid as a signal molecule in plant-pathogen interactions. Curr. Opin. Cell Biol. 6, 275-279. doi: 10.1016/0955-0674(94)90147-3

Vicini, P., Zani, F., Cozzini, P., and Doytchinova, I. (2002). Hydrazones of 1,2-benzisothiazole hydrazides: synthesis, antimicrobial activity and QSAR investigations. Eur. J. Med. Chem. 37, 553-564. doi: 10.1016/S0223-5234(02)01378-8

Vlot, A. C., Dempsey, D. A., and Klessig, D. F. (2009). Salicylic acid, a multifaceted hormone to combat disease. Annu. Rev. Phytopathol. 47, 177-206. doi: 10.1146/annurev.phyto.050908.135202

Wang, D., Amornsiripanitch, N., and Dong, X. (2006). A genomic approach to identify regulatory nodes in the transcriptional network of systemic acquired resistance in plants. PLoS Pathog. 2:e123. doi: 10.1371/journal.ppat.0020123

Ward, E. R., Uknes, S. J., Williams, S. C., Dincher, S. S., Wiederhold, D. L., Alexander, D. C., et al. (1991). Coordinate gene activity in response to agents that induce systemic acquired resistance. Plant Cell 3, 1085-1094. doi: 10.1105/tpc.3.10.1085

Wasternack, C., and Hause, B. (2013). Jasmonates: biosynthesis, perception, signal transduction and action in plant stress response, growth and development. An update to the 2007 review in annals of botany. Ann. Bot. 111, 1021-1058. doi: 10.1093/aob/mct067

Watanabe, T., Igarashi, H., Matsumoto, K., Seki, S., Mase, S., and Sekizawa, Y. (1977). The characteristics of probenazole (oryzemate) for the control of rice blast. J. Pestic. Sci. 2, 291-296. doi: 10.1584/jpestics.2.291

Wei, G., Kloepper, J. W., and Tuzun, S. (1996). Induced systemic resistance to cucumber diseases and increased plant growth by plant growth-promoting rhizobacteria under field conditions. Biol. Control 86, 221-224.

Wendehenne, D., Durner, J., Chen, Z., and Klessig, D. F. (1998). Benzothiadiazole, an inducer of plant defenses, inhibits catalase and ascorbate peroxidase. Phytochemistry 47, 651-657. doi: 10.1016/S0031-9422(97)00604-3

Wevelsiep, L., Kogel, K.-H., and Knogge, W. (1991). Purification and characterization of peptides from Rhynchosporium secalis inducing necrosis in barley. Physiol. Mol. Plant Pathol. 39, 471-482. doi: 10.1016/0885-5765(91)90013-8

White, R. F. (1979). Acetylsalicylic acid (aspirin) induces resistance to tobacco mosaic virus in tobacco. Virology 99, 410-412. doi: 10.1016/0042 6822(79)90019-9

Wildermuth, M. C. (2006). Variations on a theme: synthesis and modification of plant benzoic acids. Curr. Opin. Plant Biol. 9, 288-296. doi: 10.1016/j.pbi.2006.03.006

Wildermuth, M. C., Dewdney, J., Wu, G., and Ausubel, F. M. (2001). Isochorismate synthase is required to synthesize salicylic acid for plant defence. Nature 414, 562-565. doi: 10.1038/35107108

Wu, Y., Zhang, D., Chu, J. Y., Boyle, P., Wang, Y., Brindle, I. D., et al. (2012). The Arabidopsis NPR1 protein is a receptor for the plant defense hormone salicylic acid. Cell Rep. 1, 639-647. doi: 10.1016/j.celrep.2012.05.008

Yan, Z., Reddy, M. S., Ryu, C. M., Mcinroy, J. A., Wilson, M., and Kloepper, J. W. (2002). Induced systemic protection against tomato late blight elicited by plant growth-promoting rhizobacteria. Phytopathology 92, 1329-1333. doi: 10.1094/PHYTO.2002.92.12.1329

Yasuda, M. (2007). Regulation mechanisms of systemic acquired resistance induced by plant activators. J. Pestic. Sci. 32, 281-282. doi: 10.1584/jpestics.32.281

Yasuda, M., Kusajima, M., Nakajima, M., Akutsu, K., Kudo, T., Yoshida, S., et al. (2006). Thiadiazole carboxylic acid moiety of tiadinil, sv-03, induces systemic acquired resistance in tobacco without salicylic acid accumulation. J. Pestic. Sci. 31, 329-334. doi: 10.1584/jpestics.31.329

Yasuda, M., Nakashita, H., Hasegawa, S., Nishioka, M., Arai, Y., Uramoto, M., et al. (2003a). N-Cyanomethyl-2-chloroisonicotinamide induces systemic acquired resistance in Arabidopsis without salicylic acid accumulation. Biosci. Biotechnol. Biochem. 67, 322-328. doi: 10.1271/bbb.67.322

Yasuda, M., Nishioka, M., Nakashita, H., Yamaguchi, I., and Yoshida, S. (2003b). Pyrazolecarboxylic acid derivative induces systemic acquired resistance in tobacco. Biosci. Biotechnol. Biochem. 67, 2614-2620. doi: 10.1271/bbb.67.2614

Yasuda, M., Nakashita, H., and Yoshida, S. (2004). Tiadinil, a novel class of activator of systemic acquired resistance, induces defense gene expression and disease resistance in tobacco. J. Pestic. Sci. 29, 46-49. doi: 10.1584/jpestics.29.46

Yoshida, H., Konishi, K., Koike, K., Nakagawa, T., Sekido, S., and Yamaguchi, I. (1990a). Effect of N-cyanomethyl-2-chloroisonicotinamide for control of rice blast. J. Pestic. Sci. 15, 413-417. doi: 10.1584/jpestics.15.413

Yoshida, H., Konishi, K., Nakagawa, T., Sekido, S., and Yamaguchi, I. (1990b). Characteristics of N-phenylsulfonyl-2-chloroisonicotinamide as an anti-rice blast agent. J. Pestic. Sci. 15, 199-203. doi: 10.1584/jpestics.15.199

Yoshida, H., Shimano, S., Mochizuki, S., Koike, K., Nakagawa, T., and Konishi, K. (1989). N-Cyanoalkylisonicotinamide derivatives. US Patent, US 4804762 A.

Yoshida, K., Ogino, A., Yamada, K., and Sonoda, R. (2010). Induction of disease resistance in tea (Camellia sinensis L.) by plant activators. JARQ 44, 391-398. doi: 10.6090/jarq.44.391

Yoshida, T., Itou, A., Yamamoto, R., Tobino, T., Murakawa, H., and Toda, K. (2013). Determination of isotianil in brown rice and soil using supercritical fluid extraction and gas chromatography/mass spectrometry. Anal. Sci. 29, 919-922. doi: 10.2116/analsci.29.919

Yoshioka, K., Nakashita, H., Klessig, D. F., and Yamaguchi, I. (2001). Probenazole induces systemic acquired resistance in Arabidopsis with a novel type of action. Plant J. 25, 149-157. doi: 10.1046/j.1365-313x.2001.00952.x

Zani, F., Mingiardi, M., Ca, M., and Mazza, P. (1996). Biological studies on 1, 2-benzisothiazole derivatives vi antimicrobial activity of 1, 2-benzisothiazole and 1, 2-benzisothiazolin-3-one derivatives and of some corresponding 1,2benzisoxazoles. Farmaco 51, 707-713.

Zhang, Y., Tessaro, M. J., Lassner, M., and Li, X. (2003). Knockout analysis of Arabidopsis transcription factors TGA2, TGA5, and TGA6 reveals their redundant and essential roles in systemic acquired resistance. Plant Cell 15, 2647-2653. doi: 10.1105/tpc.014894

Zhang, Y., and Turner, J. G. (2008). Wound-induced endogenous jasmonates stunt plant growth by inhibiting mitosis. PLoS ONE 3:e3699. doi: 10.1371/journal.pone.0003699

Zhao, Y., Chow, T. F., Puckrin, R. S., Alfred, S. E., Korir, A. K., Larive, C. K., et al. (2007). Chemical genetic interrogation of natural variation uncovers a molecule that is glycoactivated. Nat. Chem. Biol. 3, 716-721. doi: 10.1038/nchembio.2007.32

Zipfel, C., Robatzek, S., Navarro, L., Oakeley, E. J., Jones, J. D., Felix, G., et al. (2004). Bacterial disease resistance in Arabidopsis through flagellin perception. Nature 428, 764-767. doi: 10.1038/nature02485

Conflict of Interest Statement: The authors declare that the research was conducted in the absence of any commercial or financial relationships that could be construed as a potential conflict of interest.

Received: 09 October 2014; accepted: 22 December 2014; published online: 26 January 2015.

Citation: Bektas Y and Eulgem T (2015) Synthetic plant defense elicitors. Front. Plant Sci. 5:804. doi: 10.3389/fpls.2014.00804

This article was submitted to Plant Physiology, a section of the journal Frontiers in Plant Science.

Copyright (C) 2015 Bektas and Eulgem. This is an open-access article distributed under the terms of the Creative Commons Attribution License (CC BY). The use, distribution or reproduction in other forums is permitted, provided the original author(s) or licensor are credited and that the original publication in this journal is cited, in accordance with accepted academic practice. No use, distribution or reproduction is permitted which does not comply with these terms. 